\title{
Entrepreneurship, Financial, And Economic Development: A Literary Review.
}

\author{
Ajagbawa O. Henry
}

\section{Introduction}

There is a symphonious feel to the tri concepts of entrepreneurship, finance and economic development. Each attracts and or follows the other in its wake and the extent of mutual reinforcement, causality and interdependence of the concepts remains an area of growing research interest in development economics, entrepreneurship, and finance.

Finance acts on economic development in an analogous manner as water acts on life. Water makes up $60 \%$ of the body mass, serving as a vital source of life to every cell of the human body, underscoring the importance of water (USGS, 2014). The gravitational pull of life to water is akin to the gravitational pull of interest rates on investment valuation (Buffet, 2002). These metaphors are intended to show the importance of finance to economic development.Financial development in a broader sense can be viewed to act as a gravitational pull on economic development or the reverse position depending on the side of the divide you stand on causality. Whereas entrepreneurship as a catalyst to economic development is a settled issue (Schumpeter, 1934, Ajagbawa, 2014), it is agreed that the process is better facilitated in a regime of robust financial development.

Financial development is an intermediation process through which entrepreneurial activities are converted to positive economic developmental projects in the economy. It is an essential part of economic development with one preceding the other or reinforcing each order, indeed, the concepts are intertwined. Financial development is said to spur entrepreneurial activities, whereas entrepreneurial engagements strengthenfinancialdevelopment, and the importance of entrepreneurial activities to economic development is well known (Schumpeter, 1934). As John Hicks noted (as cited by Van den Berg, 2012), the industrial revolution which brought about unprecedented economic development would be inconceivable withoutthecorresponding revolution in financial innovation. Whereas, the level of economic development spurned out of entrepreneurial engagement in technological innovation changed the methods and processes of industrial production significantly at that time. The nature of these relationships has been a matter of great attention to scholars

\section{Entrepreneurship}

The foundational premise establishing the nexus between financial development and economic development is credited to the work of Schumpeter (1939, p.107-123)on entrepreneurship even though some flattering reference can be alluded to earlier works of classical economist like Riccardo who had linked economic progress with the credit expansionist function of money (Robbins, 1968; p120-149), and Adam Smith who described entrepreneurs as "men of speculation" in his wealth of Nations (as cited by Van den Berg, 2012). Levine (2005) posits that better developed financial systems, through reduction of information and transaction cost, ease external financial constraints facing entrepreneurs, reduce market frictions and structural impediments facing entrepreneurs and economic agents, and the benefits of the financial system transmits and encourages entrepreneurial behaviour, innovation and investments. Croitoru (2012), Kerr \& Nanda (2009) and Chemmanur\&Fulghieri (2014) have all validated the relationship.

Morales (2003) affirm that financial intermediation boost technical innovation through identification of entrepreneurs for extension of funds to initiate new processes or to produce entirely new goods. This is consistent with Schumpeter's (1912) economic development theory which differs and challenged mainstream economics on the grandstand of innovation. Mainstream economics had maintained that resource allocation is achieved through the mechanism of the static general equilibrium framework (as cited by Hazel, 2012, Van den Berg, 2012) while Schumpeter described innovation as the impetus driving growth through the resource allocation mechanism. Schumpeter posits that the growth process under capitalism is a dynamic and changing process, generating technological innovation that constantly change the equilibrium in a non-recursive manner. Innovation through knowledge seeking culture tended to reinforce and proliferate in environment where the economy has strong predilection for technology (Carlsson, 2009). This process is on a permanent change dial that challenges the status quo, generates innovations and cause resource allocation and re allocation to drive growth in the economy. 
Schumpeter argued that the capitalist system is evolutionary as innovation pushes the economy constantly to new and better frontier. The opportunity to innovate and earn a profit pushes the economy to new discoveries and further innovation that pitches the economy on a permanent path of change. This disequilibrating process that creates opportunity for the entrepreneur to earn profits is what Schumpeter described as the process of "creative destruction". Schumpeter drew attention to the role of finance in encouraging and fostering the culture of innovation and entrepreneurship. He argued that the financial sector impacts economic development through the mechanisms of first accumulating savings, and second, channel savings to fund the most capable entrepreneurs. This facilitates the risk diversification associated with innovation (Morales, 2003) and enhances efficient allocation of investments, thus increasing productivity.

Economic growth models prior to Schumpeter's theory of economic development had assumed that savings is channelled to productive investment without cost and delays. It assumed that the factors of production (Adam Smith, 1776), land, labour and capital, just manifest into the productive process and generate output without concerted and coordinating role of an agent, and at a cost. Schumpeter main contribution was the introduction of the entrepreneurship role as the fourth factor of production which brings life into the conversion process from savings to investment through the risk taking properties of innovation and finance seeking behaviour of entrepreneurs to pursue new concept/enterprise.

He argued that entrepreneurs are economic agents who breathe life into the static general equilibrium state of the economy through the entrepreneurial process of opportunity recognition which morphs into innovation. This innovation led disequilibrating process creates a new order (Hazel, 2012). The role of money and banking in the evolutionary process of development is emphasised as critical to economic growth in as far as funding and sharing of risk associated with technology

Schumpeter's' entrepreneur is the innovator, planner, organiser that sets up the enterprise. He may be a capitalist with personal financing source or may access the capitalist (finance sector) for funding. He emphasized the distinctive roles of the Capitalist and entrepreneurs, which is maintained even when both roles are embodied in the same economic unit. This is consistent with the position of Kirzner (2013) which main path of divergence on entrepreneurship is on the equilibrating state of the economy created by entrepreneur's innovation. The path breaking work of Schumpeter that laid the foundation for the link between financial development and economic development have since been reinforced in the literature of economic development and its nexus to financial development (Shittu, 2012; Adelakun,2010; ECB,2007; Levine, R, 2004; McKinnon $\&$ Shaw, 2000) According to the ECB (2007).Financial development as a concurrent factor in economic development creates a gravitational pull on cost of capital in less developed countries by reduction in institutional and structural impediments, and raise the total factor productivity in the developed world, and these are pivotal enabling environment for entrepreneurs to exhibit the alertness to and recognition of opportunity in the market.

Indeed, both the Schumpeterianand the Kirznerian schools hold that entrepreneurship can best be understood from the prism of how opportunities are recognized, analyzed and exploited to create value and the impact on the economic system.

Table 1: Schumpeterian vs. Kirznerian Opportunities

\begin{tabular}{|c|c|}
\hline Schumpeterian Opportunities & Kirzerian Opportunities \\
\hline Disequilibrating & Equilibrating \\
\hline Creative Destruction & Restoration process \\
\hline Requires New Information & Does not require new Information \\
\hline Very innovative & Less Innovative \\
\hline Rare & Common \\
\hline Involves creation & Limited to Discovery \\
\hline
\end{tabular}

Source: Adapted from Shane 2003

Schumpeter, in the Theory of Economic Development, believes that entrepreneur is an "agent of change that is the source of creative destruction" Entrepreneur is someone who generates the change to the existing order and all the resulting vibrations in the economic system are attributable to their actions. The entrepreneurial state is always at a disequilibrating state in relation to the general economic state. Kirzner on the other hand emphasized that entrepreneur tend to generate a restoration process to the system or create a new equilibrating pattern but does not cause disruption to the system. This argument hinges on the position that the Schumpeter school maintained that entrepreneurship results to innovation that disrupts the existing order of production while the Kirznerian school emphasized that innovativeness does not disrupt rather its merely a process of opportunity recognition of a need gap in the market that has just been realized and the entrepreneurial act simply restore the system back to a new level of equilibrium

There is however, agreement that entrepreneurship starts with the opportunity recognition process. There is also agreement that opportunity recognition has an elaborate work process before the decision that an opportunity exist, is recognized and explored. The heuristic (Vaghely\&Julien, 2008) model for opportunity 
recognition maintains that an entrepreneur is prepared by knowledge of his environment, market conditions technology cultural forces which empowers them to evaluate and modify situations that lead to decision to recognize an event or activity as an opportunity for recognition and exploitation. The potential explanation of the sources of entrepreneurship coming from the interplay of psychological and non-psychological factors of the individual and its environment is also supported by the works of Shane (2003) and Fuduric (2008).

The Schumpeter school is founded on the pillar of technological innovation. This foundation challenges the meaning of entrepreneurship which is agreed to be seated on the concepts of "alertness to and foresight of market conditions" (Shane 2003, Kirzner, 1973). Shane (2003) gave a more robust and generic definition of the entrepreneurial process as entailing the existence, discovery, exploitation of an opportunity, then the acquisition of resources, the development of an entrepreneurial strategy, and the organizing process. Entrepreneurial actions/activities are activated in accordance to and only after the state of mental alertness to and recognition of opportunities have been established.The ability to identify the right opportunity is the most important profile component of successful entrepreneursand they may or may not innovate a new technology in the process of filling the gap in need/market so identified.

Lucas (1978), Zoltan, Audretsch\& Lehmann (2013) pointed out that indeed, opportunity is not an exogenous factor which the human alertness allows us to recognize and exploit but rather opportunity is an endogenous factor remaining in the realm of mental alertness. This is consistent with the position of Simon (1981) who maintains that the ultimate entrepreneurial resource is the human mind which allows the conceptualization and conversion in the mind of all situations that are open to the human.

The sources of entrepreneurship may be more robust than the position made out by the traditional school that entrepreneurs are born. Several governments across the word have at one time or the other embarked on promotion of entrepreneurial practices and innovation. The Nordic countries especially Finland, at the turn of the last quarter of the twentieth century,embarked on a strategic initiative of deliberately promoting entrepreneurship as a means of economic development. Nationally designed programs at encouraging and stimulating the growth of entrepreneurship was embarked upon by Government through policies that deliberately encouraged innovation by the establishment of the science policy council in 1979. The results however, did not match government investment towards building an entrepreneurial culture. Meanwhile, in most developing countries, people are forced into entrepreneurship as a lifestyle or to fill a service need or exploitation of imported technologies. Consistent with the definition of Shane (2003), entrepreneurship exceeds the connotation of the Schumpeterian school.

This distinction between entrepreneurship arising from the seed of innovation and entrepreneurship from other sources like life style entrepreneurship or aspiring entrepreneurship has analogous bearing with the classification methodology of entrepreneurship adopted by the Global Entrepreneurship Monitor (GEM) into an innovation led entrepreneurship or necessity led entrepreneurship. The classification highlights the level of employment in the respective economies and general HDI level which motivates people to take to entrepreneurship as a necessity or as an opportunity to innovate and exploit the economic gains from innovation. The classification of entrepreneurship state by the GEM adopts a multiphase conceptual approach to understanding the entire process in the entrepreneurship spectrum. The phase approach tracks entrepreneurial efforts and activities from the conception, idea or intention stage of potential entrepreneurs to matured functional entrepreneurs. There are five phases which typifies the life cycle theory starting from birth to death (business discontinuity of failure). It is instructive to point out that the stages are not a continuum in the sense that input at the potential entrepreneurial stage or any stage for that matter may not translate to a linear output at the next as businesses can fail or never commence beyond a particular level. Therefore sustainable entrepreneurship in an economy must be able to scope and measure the activities of each of the entrepreneurial state as described below;

1. Potential Entrepreneurs are those who believe they have the capabilities to explore and exploit apparent or not so apparent business opportunities and have the guts to take on the challenge. These intentions may or may not be realized. When realized they go to the nascent stage or remain wishful plan when unrealized

2. Nascent Entrepreneurs are those entrepreneurs' activities that moves from the planning stage to actual businesses but are less than 3 months. Given the relative challenges of starting a new business, many fail at this stage.

3. New Business Entrepreneurs. Businesses that survive the nascent stage to over three and half years are referred to as new business enterprises. Entrepreneurs will affirm that those early years are the most challenging and to cross over gives a good indication of long term sustainability. The whole spectrum of the nascent and new business stages are referred to as the total early entrepreneurial activities

4. Established Entrepreneurs are those that have gone on for about 4 years and beyond and have become stable. The entrepreneurs may or may not remain but the business has been established. Some entrepreneurs move on to set up other new entrepreneurial ventures once the job is done as it were.

5. Discontinuity of Entrepreneurship. Some business may close up and the promoters move on to paid employment, unemployment, or make them to join forces to start up a new entrepreneurship venture or go it 
alone. In all events the experience of failure itself is an essential attribute to the entrepreneurial process. It generally reenergizes prospective entrepreneurs' at a new start.

In the final analysis, successful entrepreneurship generates wealth to their owners while failure comes with financial challenges given the investment outlay borne by the joint risk takers; the entrepreneurs and the capitalist. However, there are studies that have proven that this causal relationship between entrepreneurs and wealth creation may actually hold for the reverse position. Fairlie and Krashinsky (2012) using the theoretical models of Evans and Jovanovic (1989) posits that there is a causal positive correlation between wealth and entrepreneurship. They maintained that the most well read, educated and wealthy people (the few in the $95^{\text {th }}$ percentile) are more likely to take to entrepreneurship than people with little wealth. The justification being that the wealthier are likely to have a better shock absorber in the event of failure and the fear of failure is at the most minimal level in the scheme of considerations to take up entrepreneurship.

It has been suggested that the structure and profile of the demographic index as a socio economic factor in a country is a serious considerations to be looked at in assessing the level of aspiring and willing entrepreneurs in an economy. Levesque \&Minniti (2006) showed from empirical studies that younger people are more likely to start a business than older people. So the age distribution of the population may be an important consideration to consider in looking at the rate of growth of new firms in an economy. Anecdotally, we observe that some industries, like sports, have a characteristic early retirement age for obvious accelerated physiological degradation reasons. These young retirees with significant economic power have been known to take to entrepreneurship. This observation rings true to the research findings of Fairlie\&Krashinsky (2012) that entrepreneurship attracts the wealthy than the poor. There might be an interesting research possibility on the relationship between early retirement prone industry, financial capacity and entrepreneurship initiatives.

Clearly, entrepreneurship results in the creation of new businesses, new jobs, increased productivity and all the stakeholders, including Government, supplier's buyer's regulators, and pressure groups have keen interest in ensuring success of entrepreneurship. There is therefore, a social function by each of the stakeholder if the gains of entrepreneurship is to be realized. Government as a major stakeholders must provide the enabling environment including education, legal framework physical infrastructure to make entrepreneurship thrive. In the midst of these building block enablers, would-be entrepreneurs must possess certain base qualities that sets them apart. These include, clear intentions, cognitive capacity, motivation, passion, knowledge and opportunity recognition capabilities. Xiao Ping Chen(2009) in their study concluded that preparation (cognitive alertness) and not passion drives potential investors from funding entrepreneurial ventures. Notwithstanding this conclusion, other practitioners like Steve Jobshave maintained that "it is so difficult to build a company without passion". It is safe to maintain therefore that all these profile attributes are contributory to strong entrepreneurship culture.

Pragmatically, most less developed economies are challenged with massive infrastructural deficits that makes entrepreneurship a night mare. In Nigeria for example, lack of constant power supply, bad access roads, et al, have robbed the economy of the entrepreneurial potentials in cottage industries and SME businesses springing up across the country. The result is massive unemployment of its youth estimated at over $40 \%$. The implication of the unemployment situation is social unrest and security challenges and this is self-evident in the history writing itself in the country at the moment. There is therefore, a valid connection between entrepreneurship, economic development, employment, security and related social values to be pursued by society

There are consistent themes that run around all the perspectives on entrepreneurship and the core are opportunity recognition, mental alertness, strategic understanding of resource availability and use, and the creation of a valuable good or service to the individual entrepreneur and the society at large. In all events, the engagement of entrepreneurs are such that boost productivity either by directly increasing the yield of existing production processes by new technology or by an entirely new product introduction in the market. In either event, production, factor productivity and employment is enhanced. Entrepreneurship is one of the few ventures that strikes a concurrent consistency between the often conflicting goals of privatization and socialization of economic gains. Entrepreneurship adds value to the entrepreneurs and commensurate value to society in terms of employment opportunities, taxes to government and community services to its operating environment aside the dividends to its capital providers.

\section{Finance And Financial Development}

At the heart of Schumpeter's' contribution to the theory of economic development is the concept of "creative destruction" which hinges economic development on the disequilibrating process that propel the entrepreneur to innovate and disturb the existing order. He connected the relevance of the financial sector to the evolutionary growth process by the risk sharing engagement between the entrepreneur and the banks/capitalist. Indeed, John Hicks (1969) (as cited by Van den Berg, 2012) stated that the industrial revolution could not have occurred without the concurrent development of the banking and financial markets. 
Indeed, the temporal convergence of the era of the evolution of new financing vehicles and wave of commercialization of new technologies (The Semiconductor manufacture from Silicon materials which started about mid twentieth century) (Dennis, 2013) buttresses this point. New technological innovation and inventions rode on the back of new and innovative financing vehicles like venture capital and business angels (Cantner, Dinopoulos\&Lanzilloti, 2010. P 117-136). Two distinct points stands out. First is that the new financing vehicles provided an easy conduit to commercialization of new inventions and innovations, and secondly, the existence of the flexible and adaptable new financing vehicles to share the risk of the enterprise, gave impetus and encouraged the market to a new wave of research aggressiveness and innovation (Morales, 2003). This is consistent with Carlsson (2009) position that a technological strong country is likely to be highly disposed to innovation.

In reality, one of the greatest challenges to entrepreneurship is financing. The sources of financing typically depends on the extent of the financial development of the economy. In the early and late part of the twentieth century, a couple of companies reputedly rose from the seed of untested technological innovation to fortune 500 status on account of special financing support they received (Shane, 2009; Ajagbawa, 2012). Angel is a unique and distinctive source of entrepreneurial financing which is amenable to start ups. Research evidence exists that angel funded start-ups are less likely to fail than companies that rely on other forms of initial financing for start-up (Kerr, Lerner \&Schoar, 2010). 60\% of all start-ups in America are reputed to have been funded by angels, (Shane, 2009) hence the importance of this funding source to economic development, and the debate over the causal relationship between the existence of private equity companies and economic development/innovation deserves more research attention. Suffice to say anecdotal evidence points to the dearth of such financing arrangement in the less developed economies.

Most PE funds deployed in Africa are typically by multilateral public companies like the ADB (African Development Bank), IFC (International Finance Corporation), and the PIC (Public Investment Corporation). A few true PE companies like Actis and Telios operate out of diaspora with a few establishing office in recent times to leverage on the factor led economy of host countries. The total PE deals closed since 2002 to date in the whole of Africa is about $\$ 30 \mathrm{~b}$ and PE funding to GDP is 0.1 in Nigeria compared to $2 \%$ in Israel (KPMG, 2013). Could this be a mere happenstance? Rapid economic development seemed to have trended with rapid growth in financial developments (Laeven, Levine, \&Michalopoulos, 2010) However, research has shown mixed results in different clime.

Retrospectively, the root of entrepreneurship dates back to post medieval times when specialization was encouraged upon the advent of the money economy and finance. The medieval economy was characterized by trade by barter which imposed trading rigidities of double coincidence of wants and exchange ratio challenges (Adam Smith, 1776). Every man produced what he needed and exchanged the surplus thus limiting our collective growth. In this stylized perfect world of exchange, there is no need for financial intermediation as buyer and seller of assets could locate themselves at no cost and consummate exchange of assets under perfect information environment. The need for money would have been indeed, superfluous under such stylized environment (Gorton \& Winston, 2002; Andries\&Cuza, 2009). Precisely because there is no such thing as perfect information flow and costless transaction dynamics that we have the need for financial intermediation.

The development of the exchange function of money created the need for specialization where, as Adam Smith argued, each individual would be expected to specialize in a particular area where he fared better than dissipate energy in all areas and produce sub optimally. Specialization aided innovation and further accentuated the need for the development of a financial system to drive economic growth. The role of the financial system has evolved to match and drive the level of economic growth by mobilising savings and channelling same to investments in capital goods, aiding (re)allocation of resources, generating information on the market, monitoring investments and ensuring risk diversification and management. The evolvement of a robust financial system is thus critical for economic development and countries which have more developed financial systems tended to have better economic growth (Andries\&Cuza, 2009).

Historically, the architecture of financing is in a constant state of flux given the fast pace of financial innovations leading or following economic growth. Therefore, an appreciation of financing should have a clear bearing to the concept of financial development. Even the aspect of financial access and inclusion which has no direct bearing to financing the production of entrepreneurs has significant implication in the empowerment of consumers which reflects on sales and financing of working capital of the company. A word on financial development is therefore imperative for our review.

The World economic Forum (WEF, 2011) defined financial development as the "factors,policies, and institutions that lead to effective financial intermediationand markets, as well as deep and broad access to capitaland financial services." This definition provides arobust and generic interdisciplinary perspective to the concept of financial development. The work of Goldsmith (1959) on the morphology, structure and framework of the financial system stands out in its analytical coverage of the concepts of financial development in explaining the intertwined relationship between the comparative study of economic growth and financial 
development, and illuminating its interdisciplinary dimension in economics, finance, anthropology, politics, and law.

The interdisciplinary nature of financial development is reflected in the broad key pillars of financial developments, as developed by the world economic forum;

Table 1: Financial Development Index (Fdi)-3 Pillars And 7 Sub Pillars

\begin{tabular}{|l|l|l|l|}
\hline S/N $\square$ Fdi & Factors, Policies \& Inst. & Financial Intermediation & Financial Access \\
\hline $\mathbf{1}$ & Business Environment & Banking Financial Institution & Financial Access \\
\hline $\mathbf{2}$ & Institutional Environment & Non Banking Financial Inst. & \\
\hline $\mathbf{3}$ & Financial Stability & Financial Markets & \\
\hline
\end{tabular}

The financial development construct is a ramification of the role of the financial system. At the heart of the financial system is the reduction of information asymmetry and cost of transaction between savers and users of funds in a stylized frictionless environment. In doing this the financial system performs 6 critical roles; (1) Generating market/participant information. (2) Enable resource allocation to entrepreneurs/firm with a higher theoretical Tobin's Q (Sims, 2011). (3)Monitor investments and ensure corporate governance. (4)Facilitate risk diversification and management. (5) Mobilise and pool savings. (6) Facilitate the exchange of goods and services (Adam smith, 1776). Essentially, different environments are likely to generate different levels of efficiency in the performance of these roles. Therefore, the efficiency with which a country delivers these financial system functions determines the level of its financial development (Levine, 2005). The totality of institutional enablers (policies, processes, and structures) and removal of hurdles to enthrone an efficient financial system constitute the level of financial development.

Thus, financial development describes a superstructure which ramifications includes the various branches and interdependence thereof; stock market, money market, foreign exchange market, derivatives market, institutional framework and policy impact, systems policies and infrastructure (WEF, 2011). An understanding of the various variable components of financial development and their interaction levels spells a good appreciation of the depth and breadth of the concept of financial development. For example, a financial inclusion program utilising the mobile phone channel as a strategy cannot succeed if the financial inclusion plan is not facilitated by the concurrent legal, physical, and social infrastructural plans to support the financial plan (Ahmad, 2009; CBN, 2013)

The interdisciplinary context of financial development has influenced the body of research conducted on the subject and its nexus to economic development. We have a near inexhaustible body of research work on the various pillars of financial development explaining the connection between financial development and economic development. Sadly, most of the research works have isolated aspects of financial development in explain economic growth.

For example Liua\& Sinclair (2008), Barna\& Mura (2010), Mansor (2011), Abdelbaki (2013), all suggest a causal relationship between economic growth and the stock market. Kar\&Mandal (2014) on the other hand suggest that bank based financial development is more impactful on economic development. Madon (2008), Mansell, et al (2008), and Torrisi (2009), argued a causal link between infrastructure and economic development. Singh (2008) in analysing the behaviour of the stock market in low and medium developing countries, summarised that the stock market is affected by corporate finance, corporate governance and corporate law.

Thumrongvit, Kim \&Pyun (2013) have all argued a causal link between stock market variables, monetary variables, macro-economic variables and economic development and implied the dynamic causal interaction amongst the variables. Kim, Lin \& Sue (2012) argued that banking development is detrimental to economic development, while stock market development is favourable to growth in high income, low inflation and non-agricultural economy.

Abdelbaki (2013), suggested the dynamic interaction of the comingling factors affecting economic development including banking system development, income level, domestic investments, and private capital flow. Dritsaki (2006), Odeniran\&Udeaja (2010) and Osuji\&chigbu (2012), all concede that banking financial sector influence on economic activity is substantive. Acheampong\&Wiafe (2013) posited a bidirectionalcausality relationship between FDI and the stock market which transmits to economic growth. Robinson (as cited by Levine, 2005) maintained that "where enterprise leads finance follows" implying that financial developments only responds to economic growth and is not bidirectional causal.

Ben-Naceur, Ghazouani\&Omran (2008) found out in the MENA (Middle East and North Africa) countries that stock market liberalization had no effect on economic growth and its effect on stock market development was long term only in perspective. This has significant implication for the sequencing of policy initiative range from domestic to foreign led liberalization initiatives to spur economic development.

Ghossoub\& Reed (2013), using combinations of stock market and monetary tools concluded that developed economies showed signs of correlation between stock market development and economic growth 
while less developed economies with small ineffective stock market reported no such relationship. Meanwhile the Tobin effect (Edward, 2006) was reported for developed economies for monetary policy impact on economic development while no such relationship existed for the less developed countries. Mougani (2012) of the ADB suggest that in spite of the theoretical complementarity between trade integration and financial integration amongst countries, he was unable to find any evidence to support the position that finance integration tended to accelerate economic growth in developing countries. Certain institutional bottlenecks were however noted to have possibly constrained the results.

These results are in part consistent with the conclusion of Singh (2008) that objects to the use of stock market policy initiatives to spur economic development in developing countries. He recommended the utilization of the banking financial sector to leverage economic development in these countries. Part of the reasons he gave are that the assumptions of efficient market hypothesis (Lo, 2007) of seamless information availability and flows do not hold in less developed markets plus the inhibiting quality of agency relationship, and corporate governance ethos. Corporate governance is affected by legal frameworks, pattern of corporate finance, corporate ownership and the transmission of cultural beliefs across time. Good corporate governance transmits to better efficiency levels and higher productivity and thus economic growth (LLSV, 2000; LLSV, 2007).

The conclusions reached by Singh (2008) is consistent with the stage progression hypotheses posited by Goldsmith (1959). Financial development goes through a defined stage where we see continuous improvements of its absolute and relative financial indicators. For example, the financial assets to total national asset ratio are expected to grow as the financial structures and frame work improves and drive economic development and ditto for currency ratio, external financing to internal financing ratio of corporations.

The argument on the relationship between financial development and economic growth nexus is split between the financial development lead economic growth and financial development demand following economic growth. Liang and Reichert (2012) suggest that at low level of economic growth, the relationship is likely to be demand following economic development because financial intermediation services are typically low at that level but picks up as development accelerates. At higher levels of development, financial intermediation role assumes a leading role in resource allocation and risk diversification (Liang \& Reichert, 2007). Acaravci, Ozturk\&Acaravci (2009) review of some sub-Saharan countries indicated that there is no long run relationship between financial development and economic growth whereas Kagochi, Nasser \&Kebede (2013) found economy leading banking relationship, and two way causality of the economy with the stock market for sub-Saharan countries. These research results indicates amongst others that the stage of development of an economy is influenced by and does influence the level of financial development present and required for economic growth of the economy.

These results are consistent with the WEF (2011) classification of financially developed economies. The first 10 most advanced financially developed economies were incidentally some of the most developed economies of the world according to the report of the WEF. This is not surprising as research results corroborates this fact.

The underlying technological and socio economic positions of the different geographies may hold the key to the disparitiesin the research findings and conclusions reached by the WEF. This argument gains fillip on the ground that disparities in the cost of information and transaction processing, and different political, legal, regulatory and enforcement systems in each of the geographies, creates different types of financial intermediation and market operations unique to each region (Levine, 2005). For example, the legal origin theory (LLSV, 2000, LLSV, 2009) posits that the originating source of a country's commercial and company laws affect its approach to interpretation and enforcement of contracts. This may result to differential cost structures of information processing, transaction processing, and thus the cost of the intermediation function of the financial system. Consequently, less developed economies with traditional high cost of information processing and dearth of physical and social infrastructure will most likely generate a less efficient financial system than their more developed counterparts.

\section{Economic Development}

Now, let us return to and briefly describe the concept of economic development. Leading economist have described the scope of economic development to include effecting positive changes in the economic, political, environmental, and social wellbeing of a people consequent on the adoption of a right mix of policies and processes leading to the transformation of society (O'Sullivan \&Sheffrin, 2002; Van den B erg, 2012; and Todaro as cited by Riley, 2012).

Economic development transcends economic growth. Economic growth is an increase in material output per capita (Van den Berg, 2012, p. 28) and it's a subset of economic development. Economic development encapsulates multiple and concurrent areas of development of the human capital (UN, 2013), critical infrastructure (Torrisi, 2009), environmental sustainability (Everett, Ishwaran, et al, 2010), health, 
safety, literacy, social infrastructure-independence of Judiciary and freedom of speech, and social and financial inclusion that promotes the wellbeing of the people (UNCTAD, 2013).

The HDI (Human development index) was developed by Mahbub\&Amartya (1990) and adopted by the United Nations to achieve meaningful comparability of development trends across the world. The HDI best describes the essence of economic development as a more robust and inclusive measure of development (UNDP, 2013) to the extent that the index captures the definitional issues described in the aforementioned definition of economic development. Economic development delves into redistribution of wealth by the adoption of policies and processes that tends to equalise or enhance fairness in the wealth concentration per capita. Thus economic development would entail crafting actionable policies to reverse a growth world where $17 \%$ of the world population consume $1 \%$ of global production and $1 \%$ of the world population consume $72 \%$ of global production (Yudhoyono, Sirleaf, Cameron, 2013).

We shall use the terms economic growth and economic development interchangeably to mean economic development for the purpose of the review. Table 2 list some critical factors affecting economic development, especially in Africa and prominent amongst these are Leadership and governance which in real terms dictates the path for all the other criteria. Leadership decides the path to good governance and best in class

Table 2: Factors Affecting Economic Development In Africa

\begin{tabular}{|l|l|l|l|}
\hline s/n $\square$ factors & leadership, inst. \& soc systems & finance and trade & education \\
\hline $\mathbf{1}$ & leadership \& governance & savings and investment & education \\
\hline $\mathbf{2}$ & institutional bottlenecks & external finance & tech capabilities \\
\hline $\mathbf{3}$ & cultural issues & international trade & - \\
\hline
\end{tabular}

institutional enablers and commitment to science and technology (Lee Kian Yew, 2000). Leadership directs the path for conversion from factor led economies to innovation led economies (GEM 2010) which distinguishing factor is possession of superior science and technology knowhow. Innovation led economies typically have favourable terms of trade because their products are not primary products. Good governance (Fayissa\&Nsiah, 2013) will generate the right atmosphere that attracts investment, internal or and external. Leadership or lack of it constitute a strong factor for Africa's development because of the dearth of time tested institutions. The role of leadership is increasingly diminished in relative terms when a country has strong institutions that work. The traditionalised culture of execution and best practices in a country deriving from good leadership soon manifest in institutionalised methods in subsequent periods (Marquis \&Zhi, 2010) ). But most countries in Africa have not had the benefit of such historical luxury of enviable footprints in the sands of time.

Singapore remains a classical example of the validity of leadership as a sine qua non for development of a people. A remote island, willingly abandoned by Malaysia, lacking in any material resources, dead poor, and with a potential that would be discomforting to any civilized mind, was brought to a first world status at the turn of the century by the strength of vision and character of a leader and his dedicated team buoyed by nationalist fervour and the need to succeed. The Singapore story amply dismantles any assumption of natural resources richness as a requirement for growth. Anecdotally, there seem to be a negative correlation between economic development and resource richness. Most third world countries validates this assertion

Leadership sets and dictates the tune for development. If leadership validate the need for good governance by living example, it is unlikely that a country will have bad governance. Similarly, the Singapore story tells us the ingenuity of leadership in terms of planning and harnessing the strategic congruence between its internal and external environment. Singapore achieved the status of one of the few financial and transportation hub centres of the world. Simultaneously, the leadership dedicated time to academy and science as a support on which its development initiatives must rest. Suffice to say that good governance magnets investors with a gravitational force beyond any other consideration. The political uncertainties in Russia following their annexation of Crimea and the attendant massive capital flight isa good example that illustrates the relationship between good governance coming from the polity and investment.

Now, the state of development must be reduced to a common denominator, GDP, for comparability of economic activities amongst the different countries of the world. However, there are challenges and a practical example of the challenges and difficulties of using the GDP as a basis of measurement and comparability of a country's wellbeing was manifest in the recent rebasing of the Nigerian GDP to \$510b as at 2014 (THISDAY, April 7, 2014). Now the biggest economy in Africa, meanwhile, the stark reality on ground indicates business as usual for the people (Adio, 2014). Infant mortality, literacy, school enrolment of children, security concerns, independence of judiciary, Physical and social infrastructures, and contract enforcement still remain a challenge and yet in one fell swoop, the economy is the biggest in Africa. Consequentially, the per capita GDP is north bound with little meaning to the lives of the average citizen. The use of the HDI as a basis of comparison of the wellbeing of a people is further reinforced by experiences like this which validate the weakness of the GDP construct. 


\section{Entrepreneurship, Financial Development And Economic Development}

Aside leadership, institutions, education, and social systems frailty, financial development is one of the major pillars of development. Our description of financial development so far indicates the concurrent existence of factors such as institutional factors, sound and effective judicial system, affecting both financial development and overall economic development of a country. For example the existence or lack of it of a sound judiciary have a strong impact on the effectiveness and fairness in contract execution which in turn may influence investment flows.

However, there is still a fluidity to the concept of financial development and may continue to be an evolving area. A consistent theme we can glean from our analyses so far is the lack of general applicability of the research results to all economies. Some financial packages appear suited to less developed economies while others to developed economies. Our analyses so far have narrowed down to macro-economic consideration of the interplay of financial development concepts to economic development. At this point, we commence an engagement of the various facets of financial development, its interplay with entrepreneurship, and the relevance of the concepts to the reality of the various economies in a meaningful comparative analytical perspective.

\section{Stock Market}

The capital market as a predictor of economic development appears a recurring consideration that dominates the conversation. The relationship is well documented in the literature of economic development. (Nieuwerburgh et al. 2005, 2006; Atindehov et al. 2005; Ang\&Mckihin 2007; Gries at al. 2009; Adefeso, Egbetunde and Alley 2013). An engaging slant in the conversation is the proportionate relevance of bank credit financing correlation to economic development in low income countries than their higher income counterparts, (Kim \& Lim, 2013) and that stock market accelerates economic development better for high income countries. Overall, there are mixed and conflicting results on the nature and magnitude of the causality relationship between capital market activities, bank financial activities, and economic development. We shall first elaborate on the stock market impact on economic development.

The analyses of the test of relevance of the capital market to the economy can draw context from its practical impact on the lives of the average citizen. The capital market is used to finance fledging business in the economy, provide venture capital for new businesses and capital investments through IPO (Initial Public Offer) and PO (Public Offer) aside the secondary market for capital re allocation and portfolio rearrangement purposes (Andries\&Cuza, 2009). Through the capital market operations a sizeable proportion of the citizens are encouraged and sometimes incentivized to participate and take ownership position in strategic industries and businesses in the economy through investment in shares via primary or secondary market windows (BusinessWeek, 2001. P 166).

The personal wealth of citizens may be maximised or improved from capital market activities thereby reducing poverty (Uddin, shahbaz, Arouri\&Teulon, 2014). Research evidence indicate that financial development helps to reduce poverty, but its effect may not be linear. Meanwhile Hoi and Hoi (2013) Confirm that financial sector development has a positive impact on reducing income inequality. Anecdotally, the stock market, owing to the inherent risk profile potential, may also be a catalytic source of poverty. The 2008 world economic meltdown for example witnessed a great number of families lose their financial fortune and life savings to the vicissitude of the market

Kuznets (1955) in his seminal paper (as cited by Acemoglu and Robinson, 2002) had argued that as countries developed, income inequality first increased, peaked and then decreased with developing countries represented in the ascending portion of the bell curve and developed countries, on the descending portion. The curve links inequality with per capita income. The hypothesis is consistent with several results on financial development led growth hypotheses that financial development reduces poverty and income inequality (Uddin et al, 2014; Hoi and Hoi, 2013).

However, the environmental Kuznets curve which hypothesises that environmental degradation is aggravated with development, implying poorer countries would tend to have better environment than the more advanced countries is challenged by global attention and focus to the mutually assured destruction risk potential of environmental degradation. Since the Rio conference of 2012 and preceding conferences on environmental sustainability and economic growth, all counties of the world, rich and poor are encouraged to employ ecologically friendly means of production, collaborate and share models of best practices, accentuate the use of existing platforms, promoting environmental sustainability, and construct methodologies for the evaluation of policies on green economy as a social means of poverty eradication (Babonea\&Joia, 2012; Taplin, 2013; UNRISD, 2012). In summary, there is a potential for exploitation of the environmental waste in society and the rich counties appeared to have optimised this potential by generating industries around the process, and thus expanding the frontiers of output and employment. 
As poverty is reduced (Uddin et al, 2014) and income equality enhanced from financial development (Hoi and Hoi, 2013), the growth of personal incomes and wealth of citizens are further enhanced. Enhanced personal income and wealth drives consumption. There is an established nexus in economic theory (Keynes, 1936; Breido\&Tregub, 2009) between personal income and wealth, and consumption pattern. This consumption pull process drives economic growth. Increased consumption pattern has been noted to correlate to improvement in stock index performance like the NASDAQ. There is a logic to these observations as falling stock prices diminishes household investment portfolio and wealth and thus affect their spending plans. Gloede and Rungruxsirivom (2013) suggest that financial development is associated with a larger volume of productiveinvestments which translates to improvement in the financing of consumption.

The size, structure and behaviour of the capital market could be used to gauge the size, (Alajekwu, 2012) direction and impulse of the economy. What better dramatic explanation than the loss of the all share index at the Nigerian stock exchange from 66,371.2 points by March 2008 to 37,888.47 by the corresponding period in 2014, a market value plunge of approximately 43\% (NSE, 2014). Most of the lossesoccurred in 2008 to 2009 and characteristic of global trend in stock markets at that time.This is reminiscent of the Asian financial crisis of 1997 which in part is attributable to the exodus of hot money from the financial system in Asia, triggering the collapse of the overall financial markets of the local economy (Das and Dutta, 2013). There is however some conversation on the logic of whether the economy transmits signals to the stock exchange or the stock exchange transmits its challenges onto the economy

A stock market with significant dependence on foreign funding sources might get an almost instantaneous transmission of disequilibria in foreign markets on its stock market activities as much as local financial crisis can spur capital flight (Das \&Dutta, 2013). Rewane (as cited by Chima, 2014) alludes to the "hot money" component of FDI funding portfolio investment in the stock market in developing countries as accounting for the near instantaneous transmission of global crisis onto the economies of developing countries. Typically, sell down behaviour and capital flight by foreign investors accompanies financial crises at home market which creates panic in its wake, liquidity challenges that eventually suck up funding from the real sectors of the local economy, thus exacerbating production, employment and other macro-economic growth indices.

Other research work appears to contradict the position of Alajekwu (2012). Roger Aliaga-Diaz (as quoted by Paul Lim of the NY Times) asserts that only P/E ratio came any close (43\% of stocks) to connecting stock performance and size to economic growth. The research used proxies like market price-to-earnings ratios, growth in gross domestic product and corporate profits, consensus forecasts for gross domestic product and earnings growth, past stock market returns, dividend yields, interest rates on 10-year Treasury securities, and government debt as a percentage of GDP over the period of 1929 to 2012 and concluded that the relationship between economic development and capital market is spurious on a year on year basis. For example in 2012, while the economy grew at $2 \%$, the average returns on stocks in the US, Europe, and Japan were at $15 \%, 18 \%$ and $12 \%$ respectively, indicating a short term disconnect between both variables.

The market capitalization to GDP ratio provides an indication of the size and depth of the capital market development in an economy. Our review indicated that most high income countries tended to have a higher total market capitalization (TMC) to GDP ratio than the lower income countries. By 2012, the US, UK, Japan and France had TMC to GDP ratio of $114 \%, 112 \%, 61.8 \%$ and $69.8 \%$ respectively, while their lower income counterparts, Kenya, Egypt, Ghana and Nigeria had a ratio of $36.3 \%, 22.1 \%$, 8.5\% and $21.5 \%$ respectively (World Bank, 2012). These statistics merely validate the research evidence that lower income countries have a less developed capital market than their developed counterparts, and the funding contribution of the capital market in relation to bank credit to economic development tended to increase as the economy transmits to higher level of development (Thumrongvit, Kim \&Pyun, 2013).

Financial observers point to the potential reflection of stock price movement on asset reallocation activities. During the dot com crash of the late twentieth century, there was a rapid loss of value in the NASDAQ index reflecting loss of confidence in the technology stock which witnessed rapid reallocation of capital from the new economy of dot com companies to the old and safe economy of the S\&P 30 (Roche, 2000). Thus stock market performance level could ignite confidence crises that lead to portfolio rearrangement and capital reallocation from one industry to another which has a direct, primary issue effect and indirect, secondary market trading implication on the market. Bertella, Pires, Feng, and Stanley (2014) noted a positive correlation between average confidence and return rate, indicating that market sentiment is an important driver in price fluctuations.

According to Schumpeter (as cited in Mansor, 2011) stock market development is beneficial to the economy since it provides liquidity and avenue for risk taking, sharing and diversification, thus allowing for efficient allocation of resources to productive investment outlets. This reflects from the results of the co integration, and error correction test which indicated a sound relationship between economic development and the capital market, and the position on financial market being rather opaque (Mansor, 2011). Brunner Meier 
\&Pedersen (2009) however, affirm the mutual reinforcing relationship between market liquidity and funding liquidity.

A liquid market creates marketability and convertibility of position to liquidity and reallocate funding to desiring investment. A robust funding market creates sufficient liquidity to drive the stock market liquidity and reinforces the market liquidity. Similarly, market liquidity can dry up, react to volatility in the funding market and can be subject to flight to quality which affects the market liquidity (Brunner Meier \& Pedersen, 2009). Firms sometimes list in foreign bourses as a means of accessing better quality funding sources and robust tradability of their shares to enhance market liquidity. As a result of flight to safety abroad, the proportion of trading abroad in the shares is enhanced and becomes negatively related to the liquidity of firms in the domestic market (Levine \&Schmukler, 2005).

There is a long term co-integrating relationship between the stock market and GDP (Kolapo\&Adaramola, 2012). This is consistent with the work of McMillan and Wohar (2012) that suggest, from a study of 200 years of panel data, that there exists a long term relationship between stock prices and real output with both variables exhibiting significant equilibrium reversion, but more rapid reversion rate for the stock prices. Stock prices reverts faster to equilibrium than real output because, first, traders are able to easily rally confidence in the market once uncertainties relating to information asymmetry flows are reasonably clear, noting the positive correlation between confidence and stock price movement (Bertella, Pires, Feng, and Stanley, 2014). Secondly, there is a lag period for real output to respond to stimuli and may not respond as fast as the rate of reversion of stock prices to equilibrium.

Stock market performance is transmitted to the economy through price impulses and capital re allocation activities. However, the stock market handles not only equities. Most exchanges handle equities, bonds and exchange traded funds (NSE, 2014) and derivatives. Bonds are either corporate or government, and government bonds are typically project tied to specific infrastructure and so the immediate impact on economic development is easily ascertainable, traceable, seemingly palpable/tactile and measurable in real time. This is consistent with the research evidence provided by Thumrongvit, Kim, \&Pyun (2013) that both equities and government bonds are positively correlated with economic development while the relationship between corporate bonds and economic development is not so defined. They also suggested that the contributing role of bank credit to economic development diminishes as the bond market develops.

Kim and Lin (2013) provide further evidence from their research that the contributing role of bank credit to economic development diminishes as the capital market develops. He discovered that shallow capital market, lacking in depth, is a characteristic of underdeveloped low income countries while high income countries are typically characterized by a more developed capital market (Thumrongvit et al, 2013). The banking financial segment is more developed in relative terms to its capital market and so have more bearing to economic activities and development in less developed countries. However, as the economy transmutes from underdevelopment to a developed state, and exhibiting higher income levels, so does the capital market develop alongside and the proportion of the contributing level of banking financing of economic development begin to diminish in favour of capital market financing. Anecdotally, we see evidence of high rate of massive infrastructural development; toll road construction, shopping malls, toll bridges et al dotting the Lagos landscape in recent years, and all funded from the Lagos state $\$ 507 \mathrm{~m} \mathrm{14.5 \%} \mathrm{per} \mathrm{annum} \mathrm{bond} \mathrm{maturing} \mathrm{in} 2019$. (Reuters, 2012; Lagos state, 2012)

This position is contradicted by research evidence that suggest that bank financing bear no relationship to economic development while acknowledging the causal relationship between stock market and economic growth (Margues, Fuinhas, Margues, 2013). Dritsaki and Bargiota (2006) affirm that stock prices tended to follow credit market (bank financing) and thus economic development. The research concluded that there is a bidirectional relationship between banking credits and economic growth and stock market. Anecdotal evidence in Nigeria suggest that the liberalisation of credits in the banking sector pre 2009, especially the very liberal margin loans scripted specifically for obligors to purchase equities, unleashed liquidity on the market that triggered unprecedented buy behaviour on the stock market. This is consistent with the results of Brunner Meier \& Pedersen (2009) who maintain that the funding market and the stock market liquidity are mutually reinforcing.

For the most part, the prelude to the 2008 world economic crisis created easy and unrestrained access to liquidity, fuelled market activity and created unrealistic and unsubstantiated index and stock price levels. The underlying and unrealistic economic fundamentals of the market resulted to poor and negative yield and investors soon discovered most IPO were overhyped. (Burgess, Grant, and Demos, 2014) resulting to IPO fatigue in most of the markets. From the most sophisticated capital market in the US to a developing one in Nigeria, this theme resonated and there was a "quiet price strike" by most investors resulting to slow down in the IPO market. Some analyst believe the global economic down turn explains this slowdown but years after the recession officially stopped, investors appear not to have regained their appetite for IPO (Levitov, 2013). There has been no IPO issue since 2011 to Q1 of 2014 in Nigeria with efforts by the exchange to kick start the market ongoing. 
A salient issue for mention in the IPO market as an indicator of economic development is the absolute number of IPO in an economy. Statistics indicate that between the period of 1980 to 2012, an average IPO of 233 were closed in the US annually (Ritter, 2013), while an average of 248 IPO were closed in the UK annually between the period 1995 to 2014 (LSE, 2014). In Nigeria, a total of 88 IPO were recorded between 2006 and 2010, the most active IPO period in the history of the capital market in Nigeria, fuelled mainly by the banking consolidation exercise of 2006. At that, only an average of 18 was recorded annually and non in the intervening period of 2011 to Q1, 2014 (Burgess, Grant,\& Demos, 2014). Aside investors' fatigue, most firms are now relying more on internally generated fund to finance their CAPEX (capital expenditure), perhaps for fear of IPO failure.

A critical factor that tends to play down the capital market size of developing markets like Nigeria is the low level of participation in the market. There are as many top companies on the stock exchange as there are not in Nigerian. The inclusion of some major private companies would fundamentally change the size and structure of the market capitalization. For example the telecommunication industry (MTN, AIRTEL, ETISALAT AND GLO) controlling combined annual industry turnover of over 90\% (Nwadike, 2013) of industry turnover of $\$ 9.3 \mathrm{~b}$ in 2013 , have no representation on the stock exchange. (NSE, 2014). It is important to note the contextual importance of the telecom companies which annual turnover represents $37 \%$ of the annual revenue of the country in 2013. Similar examples exist in the Oil and Gas industry where Shell, Mobil Producing and some other majors are not quoted on the stock exchange. The inclusion of these major stake holders of the economy would be a game changer and remains a challenge for the managers of the stock exchange and the economy at large.

Domestic savings is considered a factor influencing investments in capital goods through the transmission process of the financial system and thus impacts on economic growth. Research evidence (Ezeoha, 2009) has indicated in Nigeria that stock market development promotes private investment flows feeding from domestic savings, and thus enhancing economic development. This contradicts the findings by Pal and Mithal (2011) that domestic savings have an insignificant relationship with capital market activities. The inconsistency might not be unconnected with a lag effect of the explaining variables. Savings are channelled towards investments at some future dates and unlikely that a contemporaneous relationship between savings and stock market (investment in assets) can be scripted except there is flat growth in savings on a year on year basis. The result by Ezeoha (2009) however suggest that the stock market development have not been able to encourage the flow of foreign private investment into Nigeria

This is an interesting research result because it is totally incongruent to anecdotal evidence of what has happened and is happening in Nigeria. During the period preceding the economic down turn in 2009, Nigeria was a preferred destination for foreign direct investment (FDI) and approximately $20 \%$ of all FDI coming into Africa in 2011 found home in Nigeria (UNCTAD, 2012). Even though new markets like Ghana and Angola are developing and cutting into the flows coming into Nigeria, It remains the largest beneficiary of FDI into Africa. A sizeable chunk of that went into the stock market either through the secondary or primary window of the market.

It is suggested that because of the liberalization of the investment laws in Nigeria (NIPC, 1995) and the (Foreign Exchange Act, 1995) which allows foreign brokers to partake in the bourse and repatriate profits with limited foreign exchange rigidities or inhibitions, the FDI flows were significant, not only for the purpose of real investment but for speculative trading given the reasonably stable exchange rate regime (Nwogwugwu, 2014). This partly explains how the global economic recession contagion, caused by the subprime crisis was almost instantaneously transmitted to the Nigerian economy when the FDI began to sell and repatriate under the strangulating credit and liquidity challenges faced by parent investors abroad.

Amati, Ardavin and Fershtman (2004) maintained that control of corruption, the rule of law, regulatory quality, Government effectiveness and absence of bureaucratic bottlenecks, and political stability could be strong factors in encouraging the flows of investment into a country. In a comparative study of Nigeria and Malaysia, they maintained that Malaysia is able to attract better FDI and enjoy better economic progress than Nigeria because it has better institutional and regulatory framework and systems than Nigeria. Notwithstanding the relatively poor state of the business environment in Nigeria, it's able to attract more FDI than most other African countries. A combination of two factors explains this, first, the permissiveness of its financial system that allows significant speculation gains on its currencies (Nwogwugwu, 2014), and second, the fact that real opportunities exists in Nigeria in comparative regional terms on account of its population size and growing middle class.

The Stock market efficiency may be affected by the level of money demand in the economy. According to research evidence from the study of Kumari and Mahakud (2012), there is unidirectional causality found betweenstock prices and demand for money. Stock prices granger causes money demand but not in reverse manner. This is consistent with the logic and theoretical argument as we expect that as stock prices rise,equitiesbecome more attractive and the herd behaviour (Lux, 2006) triggers increased demand for moneyin order to facilitate the transactions. As Gomme (2005) asserts "bubbles mislead managers into investing when it 
is not profitable, but this becomes apparent after the bubble burst", and the herd assume a new direction. The research (Kumari\&Mahakand, 2012) further established a unidirectional causality from money demand to exchange rate.

Anecdotally, we see evidence weekly in the Nigerian money market that interest rates spike penultimate the bid day for foreign exchange auction and relaxes at its conclusion. Interest rate spikes weekly following excessive demand over supply of local currency in pursuit of foreign exchange. The research also found that there is aunidirectionalcausalityfrom money demand (M1, M2) to interest rate (TBR). It suggested that interest rate reacts for any change in money demand but not in reverse, while there is a unidirectional relationship between demand for money and inflation.

The results established by Kumari and Mahakud (2012) provide the basis for the evaluation of the impact of macroeconomic variables on economic growth in an economy. As Warren Buffet noted "Interest rates act on financial valuations the way gravity acts on matter: The higher the rate, the greater the downward pull. That's because the rates of return that investors need from any kind of investment are directly tied to the riskfree rate that they can earn from government securities. So if the government rate rises, the prices of all other investments must adjust downward, to a level that brings their expected rates of return into line. Conversely, if government interest rates fall, the move pushes the prices of all other investments upward".

This is consistent with the research result posted by Alam (2009) that there is an inverse relationship between stock prices and interest rates. The valuation of financial assets must consequently re-establish a new equilibrium value as interest rate move that would make it competitive in terms of comparable yield available in the risk free market. Warren Buffet (2014) summarised this position succinctly "the percentage of total market cap (TMC) relative to the US GNP is "probably the best single measure of where valuations stand at any given moment."

\section{Bank Credits}

It is possible to gain some epistemological insights into the theoretical distinction of financial development nexus to economic development. Acaravci, Ozturk, and Acaravci (2009) suggested four possible hypotheses for the consideration of financial nexus to economic development; (1) Asymmetric information theory where market is characterized by free information, no transaction and monitoring cost. There would be no need for financial intermediation. (2) Economic growth induces financial development. There are evidence that support this theory (Acaravci et al, 2009). (3) Bidirectional casualty approach. Financial development and economic growth are mutually or bidirectional casually and (4) Financial development and economic growth are causally independent. Odhiambo, (2007) noted no banking financial nexus to economic growth but confirmed stock market impact.

Acaravci, Ozturk, and Acaravci (2009) found from a 30 year (1975-2005) study of 24 sub-Saharan African countries, that no relationship existed between financial development and economic growth but established a bidirectional relationship between GDP and domestic bank credit. The limitations of the model imposed by the variable selection might not go unconnected with the final research result. They used bank credit, private sector credit, and liquid liability of the financial system to explain economic growth defined as real GDP per capita.

The research evidence by Acaravci, Ozturk, and Acaravci (2009) linking bank credit to economic growth has been buttressed by similar research evidence from the work of Osiji and Chigbo (2012), who from a time series data of 1960 to 2008 in Nigeria found positive relationship between money supply, and credit to the private sector to economic growth. The research evidence of Shittu (2012), Gromb and Vayanos (2010), and Anad\&Subrahmanyam (2008) also corroborate the results.

Bank credits have been shown to causally affect economic growth. Both theory and research evidence supports the position. (Schumpeter, 1939.P 108-131) and (Kizys and Pierdzioch, 2010). The underlying factors that allow banks to create credit should present more interest to us in our analytical discussion of how bank credits affects economic development. Anecdotally, only healthy and performing banks have capacity by logic and regulation (BOFID, 1991) to create and grant credits and so only profitably run financial institution can be represented in the credit creation process of the economy. Meanwhile a collection of endogenous and exogenous factors affects this very capacity to remain profitable over time. The endogenous factors are within the control of management and from practitioner perspective comes down to visionary leadership, constant reinforcement of the vision by management, learned and shared culture, entrenched and deep-seated (Kotter, 2012) over time that becomes the default pattern of behaviour in the organisation, and excellent execution capabilities. However, the exogenous factors are outside the control of management, but have serious impact on performance and ability to grant credit to customers.

Research evidence has shown that exogenous factors as business cycles affect bank performance (Kizys and Pierdzioch, 2010). Economic downturn typically triggers low loan demand and more often higher loan default rate while the reverse stands (Takamura, 2013). He affirmed that interest rates spread and loan default rates are counter cyclical to economic upswings. This is the response of the money market to the goods 
market business cycle fluctuations. Low loan demand is symptomatic of low sales occasioned by low demand for goods or excess supply in the market. Schumpeter (1939) explained the natural process of the business evolution as a natural organic working of the general economic equilibrium and the disturbances therein. A season of effective demand attracts investments, and profit making in the long term attracts more than a fair share of what the market can accommodate leading to what Schumpeter (1939, P132-197) described as "prosperity plateau" The intrinsic entrepreneurial impulse reallocates resources from the saturated market leading to lags in production with a consequent slowdown or recession in the economy. The lags in production transmits to the money market expressed as low demand for credits which impacts bank's profitability

The contours in the business cycle trends are natural expectations from the evolutionary process (Schumpeter, 1939) but which may also be escalated by other external influences like natural occurrences (Earthquake) and man-made disasters like 9/11. Business leaders need to appreciate the historical perspective of these types of external factors which may affect business cycles, but not as a way to forestalling future occurrence -because they must happen when they happen, but to provide some understanding of the context, nature, scope, and duration, to afford potential planning scenarios in dealing with the future. Therefore, our understanding of business cycle must be situated in the two parallel of external and internal factors. The external factors may totally over shadow the internal that it makes nonsense of our forecasting abilities based on historically observed fluctuations even after the series are de-trended for stationarity (Cromwell, Hannan, Labys\&Teerraza, 1994).

Business cycle impact on banks performance and capacity to grant credit is well laid out in theory and practice (Schumpeter, 1939; Kizys and Pierdzioch, 2010) As banks make profit, they are expected to appropriate into reserves (Basel Accord, 2010) to capacitate them to handle big ticket transactions in the future when the opportunity arises and to prepare a buffer- war chest- to accommodate potential losses in the future.

Banking business by nature is risky (Bank, 2012) and our business decisions are based on expectations that may or may not be realised. When realised, the economy remains at equilibrium, otherwise we have volatilities which may include loss making (Basu, 2011). When losses occur,thecapital reserve build up serve as a buffer or shock absorber. Therefore, the growth in banks size is expected to be accompanied by commensurate growth in its capital buffer. There are research evidence however that indicates a robust negative relationship between capital buffers of banks and the business cycle (Mahakud and Dash, 2013). They argued that during upturns in the economy, banks report excellent return on assets, but instead of appropriating a portion thereof to reserves, basically pursue aggressive dividend pay-out and so the proverbial savings for a rainy day is ignored because the risk posture of such banks are to expect continuity in upswing of the business trend. There are other research evidence that supports the procyclicality of capital buffer in banks which explains a category of banks that have serious risk management outlook and prepare for the rainy day.

The implications of the research findings by Mahakud and dash (2013) is that banks exhibiting countercyclicality of capital buffers are likely to degenerate their reserves in times of economic down turn and so constrain their credit creation capacity and in times of economic upswing, when they typically embark on aggressive dividend pay-out, they lose out on opportunity to grow capital to take advantage of bigger bankable opportunities in the future. Takamura (2013) have associated higher levels of output, investments, consumption and new loans to business as pro cyclical occurrences in the business cycle. In the macro space, banks buffer capital exhibiting counter cyclicality are likely to limit macroeconomic growth and promote the "too big to fail" syndrome (Sorkin, 2009). Buffer capital exhibiting counter cyclicality implies a high risk embracing bank with high dividend pay-out culture in times of booms and little retention to beef up capital for the rainy day. Therefore the slightest exposure to downward swing in the economy will provide very little capital buffer to accommodate the heavy default associated with downswings in the economy (Takamura, 2013). This behavioural trend was partly catalytic to the 2008 global economic meltdown.

At the extreme of the argument that business cycle affects bank performance and by extension its capacity to extend credit, is the position that bank performance are insulated from business cyclicality. Financial institutions have different market dynamics (Mckinsey, 2008) and may not linearly respond to the pattern of economic growth in the organic manner described by Schumpeter (1939). Because of the uniqueness of banks operational dynamics including ability to create money, cutting edge financial product innovation, unique market structure and characteristics, opportunity for external markets, and the increasing level of global financial inclusion which is swelling its clientele base across the world, banks predilection for profit making is palpable and intense regardless of the state of the business cycle. Anecdotally, and from a practitioner perspective, the profitability performance of banks in Nigeria appears invariant of the business cycle, and a testimonial of the ever increasing opportunities and growing revenue streams and sources, at least up to now. The future landscape is another matter entirely.

The sentiment of systemic risk exposure of the economy to failure of the big banks fuelled the executive hubris of certain CEO like the case of the Lehman Brothers (Sorkin, 2009) who could have exploited other take-over options to save the institution from impending liquidation. Consistent with the systemic importance sentiment, most big banks were not allowed to liquidate but rather their loss position nationalised, 
either in the US or Nigeria. The Nigerian case laid out an elaborate process involving an asset management company (AMCON, 2010) establishment to buy toxic assets and give the banks a new lease of life under a state guided merger situation that further trimmed the number of banks in the country (Ajagbawa, 2011). Like in the US, barely a year after the bailout, the emerging institutions had commenced massive dividend pay-out and return to business as usual, whereas manufacturing and the real sector continued to totter long after the crisis caused by the banks. As predicted (Takamura, 2009), there was a lull in loan demand consequent on the recession. Has the right lessons been learned or are we primed for another wave of disaster (The Rational Walk, 2010)

Back in Nigeria, the banks account for $30 \%$ to $80 \%$ of daily trading volume whereas banks represents only 14 of the 200 companies quoted on the exchange (SEC, 2014). It is estimated that banks account for about $30 \%$ of the market capitalization hence their strategic importance. Contextually, this importance is doused by the absence of all the leading companies in the two leading sectors of the economy, Oil and telecoms on the stock exchange (NSE, 2014). The systemic importance of the banking sector is indicated by the velocity of transaction, profit performance, and share price valuation. And part of the reasons for the continuing stellar performance of the banking industry in Nigeria owes to the deepening of the consumer market buoyed by the growing middle class, and on the other side of the divide the poor performance of the industrial index reflects the dwindling manufacturing base explained by the plethora of infrastructural support challenges.

\section{Financial Access}

Most developing countries like Nigeria have a poorly banked population. The population banked ranges from 5\% in Pakistan to about 25\% in India (Barksaas, 2012), and Nigeria estimated at 25\% (CBN, 2012). The low rate of banked population is attributable partly to poor credit history, limited access to bank branch and other bank channels, trust and literacy issues. With population at over $170 \mathrm{~m}$ people (World population, 2014), a financial inclusion strategy will usher an era of unprecedented profit making to the banks. The further broadening of the channel landscape to virtual banking and other alternative platforms with attendant distribution cost reduction for banks will mark up performance of banks while moving the economy to a cashless state. It is unlikely that the pace of innovation in the industries will slow down any time soon as customers' demand and needs appear to be the impetus for product innovation in the industry (Bofondi, 2006; Siegel, 2013), and customers' expectations are relentless.

In particular, banking on the go (banking on mobile platform devices) continue to revolutionize banking habits and has accelerated financial inclusion growth across the world (Grealish, Mohr, Rutstein, et al, 2011). The payment system using the mobile phone has become accepted by the poor and low income rural dwellers. The growth rate of acceptance and use of the mobile channel has outpaced brick and mortar and other channels of distribution by banks. In Kenya for example the popularity of the M-PESA (Safaricom, 2014), a mobile-phone based money transfer and micro financing service, has captured world attention including features in The Economist (2013). In Nigeria, millions of customers have signed on to the mobile money platform as a means of payment, receipts and transfers amongst other banking services including micro finance loan availment.

The fast pace of acceptance of the mobile channel for financial services is not unconnected to the rural customer literacy status, social status and trust issues. There is absence of bank branch, and alternative channels in the rural areas owing to poor infrastructural support (BCG, 2011). The rural dwellers often relied on informal arrangements for meeting their banking needs. But with the advent of mobile banking which brought banking to the telephone handset, the rural poor has adopted banking services and are able to perform simple banking payments, receipts and transfer services. Microfinance has accentuated and accelerated rural banking development (Yunus, 2013), and the intertwined effect of microfinance banking and mobile banking would appear to have galvanized rural banking behaviour across the developing world. These developments affects economic developments through the multiple channels of savings mobilisation, employments and SME generation which fuels entrepreneurial activities in the economy.

The single most important catalyst to this development is the rapid development and accessibility of mobile telecommunication across the world to the poor. In Nigeria for example telephony was $0.7 \mathrm{~m}$ in $2000,4 \mathrm{~m}$ in 2002 and has grown dramatically to over $128 \mathrm{~m}$ active lines and $247 \mathrm{~m}$ installed capacity lines as at December 2013 (NCC, 2014). In a country of over 170million people, and with over $70 \%$ living in the rural areas and estimated national telephony penetration rate of 70\% in 2013 as against $0.55 \%$ in 2001 (Nwadike, 2013), it is clear that rural telephony adoption rate has been impressive, transformational, and gradually reflecting the concurrent adoption of mobile banking services in Nigeria and across Africa.

Kenya with its M-PESA has the highest mobile banking adoption rate in Africa, Ghana at $20 \%$ while Nigeria at 2\% (KPMG, 2013). However information from a practitioner perspective, and evidence from only one financial institution, it is not unlikely the figures for Nigeria must have tripled at the least in the last year. Evidence also exist that other alternative non "brick and mortar" channels (ATM, POS, Call centre, and 
Internet) are on the increase and are fast substituting (Deloitte, 2008) for the traditional channel of distribution both in the urban areas and gradually making inroads to the rural areas(Yurcan, 2013).

This is a testimonial that a new dawn in banking has taken root on the concurrent development in the telecommunication industry. Research evidence shows that half of the world have no bank accounts and less than $30 \%$ of companies have access to bank loans in developing countries (World Bank, 2012). It is against this background that the mobile banking revolution has helped to accelerate the achievement of financial inclusion targets. The economic spinoff of financial inclusion include enhancing depth and increasing access to financial services and facilitating the creation of new jobs in the telecoms infrastructure companies and the agency banking services in the millions across the poor countries of the world, from South America to Asia and Africa. Savings, payment penetration and access to micro finance have improved (CBN, 2012). Financial inclusion facilitate deepening and broadening of financial access and through the financial inclusiveness of the rural areas, broaden savings and other monetary aggregates and thus augment better monetary policy management of the economy (Mbutor\&Uba, 2013).

These developments have also generated economic externalities as the new payment system has eased access to credit, eased payment, receipts, and bank transfer services in the rural areas, and increasingly converting the economies to cashlite (Fripp, 2013) economies with its attendant economies of scale for all. Clearly, this is one of the most important contribution of financial development to the economy of poor countries not only in terms of creating more wealth (Gloede et all, 2013) but most importantly in addressing redistribution of wealth as the most affected people benefiting from the business and social externalities of the developments are the lower income groups (Hoi \& Hoi, 2013; Uddin\&Shahbaz, 2014).

Concurrency in multiple infrastructural developments to aid financial system development resonates across the financial markets. Specifically financial access deepening is very dependent on physical infrastructural development. The mobile banking we discussed earlier is one of the several channels for promoting improved financial access, whereas financial access is a key pillar of a financially developed economy (WEF, 2012). Other inclusive non-traditional channels that could enhance and promote financial access include but not limited to number of "brick and mortar" channels per capita, ATM and POS per capita and internet banking penetration. Consistently, the internet, ATM and branch bank penetration rate for developed economies are far ahead of their less developed counterparts. (Internet World Stats, 2013, World Bank, 2013). For example, Africa's internet penetration rate is $15.6 \%$ compared to the rest of the world at $37.7 \%$, only $7 \%$ of world internet users are Africans. Nigeria account for $29 \%$ of the African internet users while Ghana is $2.1 \%$ and the mix reflecting a concentration of Nigeria, Morocco and Egypt making up over 90\% of the internet users in Africa. (Internet World stats, 2013).

The modal number of ATM and branch bank per 10,000 population in most developed countries are about 10 and 3 respectively, while the average in Africa is less than 0.5 for both ATM and branch bank. Ghana, Nigeria, Egypt and Morocco at 0.54, 1.14, 1.06 and 2.35 average for ATM and 0.57, 0.58, 0.47 and 2.34 respectively for bank branch respectively, with Morocco being an outlier. Banking channel distribution is a discriminating financial factor between developed and developing countries as inferred from the statistics and consequently can be impactful in accelerating financial development efforts. The impact channels accentuates and enhance financial inclusion, expand wealth creation potentials through direct job creation in the channels network expansion and the accompanying derived service industries.

Channel expansion and penetration rate is physical infrastructure dependent. The physical assets, power, routers, communication equipment's et al are essential to support effective deployment. Therefore, as the channel deployment grows, so also does power and the other independent asset variables. The electricity power (KW) generation per thousand population in Nigeria, Ghana, Japan and the USA for example is $0.023,0.08$, 0.99 and 1.53, implying that Ghana and USA produces 3.5 and 66.5 times more electricity to its citizens respectively than does Nigeria. Apparently, power shortage in Nigeria lead banks to procure their power generation infrastructures to drive development in this area, thus accounting for the very high cost of alternative channel deployment in Nigeria. Financial access penetration rate can also reflect from the number of corporate and retail customers of banks and the extent of financial product and vehicle availability in the economy. For example, private equities are a good pointer to funding Greenfield projects and early developing companies across the world (Berkery, 2008), and the extent of funds flow of private equities could provide an indication of the direction from which economic growth could be expected in the world. (UNCTAD, 2013)

\section{Mortgage Financing}

The GSM revolution provides compelling evidence of the connectedness between infrastructural, structural and policy framework development and the effectiveness of the financial system in promoting economic development. An apt description to buttress this position is the multiple variable interactions constituting the Nigerian national housing program implementation. The Nigerian Mortgage refinancing company (NMRC, 2013) was established in 2013 as part of an integrated housing plan, "the Nigerian Housing Finance Program" by the federal government. The housing program recognised three components to dealing 
with the identified 17m housing units gap (Ayere, 2013); (1) mortgage financing challenges and development of secondary mortgage markets, (2) Land acquisition and legal framework challenges including laws on repossession and (3) Housing development and construction (CBN 2013).

While the mortgage refinancing is one leg of the three pronged strategic drive to deal with the housing deficit in Nigeria, it is recognised that resolving the financing issue is unlikely to resolve the housing problem if the other two legs of the equation are not concurrently prosecuted. This is the very essence of the complementarity of other institutional and policy frame work support towards financial developments in furthering economic growth (WEF 2012).

The mortgage refinancing is a PPP which is planned to provide increased liquidity through the issuance of long term bonds to the market (CBN, 2012). The company refinances asset created by primary mortgage institutions and commercial banks at rates affordable by the low income earners to access mortgage and own their personal homes. Through collaboration and policy enhancements efforts in the mortgage industry, it could also influence construction cost and structure of the business as a whole to provide better efficiency levels overall.

The importance of the mortgage business to economic development can be understood within the context of its relevance and impact on GDP of countries. The Mortgage to GDP ratio in the US and UK is 73\% and $81 \%$ while that of India and South Africa is $6 \%$ and 3\% respectively. The ratio is $0.55 \%$ in Nigeria (Ayere, 2014). There is massive externalities and economic ripple effects that would accompany growth in the housing sector of the economy. Imagine the spin offs, enhanced employment, savings generation, and general macroeconomic stability that would take place if Nigeria were to achieve a 50\% housing to GDP ratio.

The NMRC would basically be underwriting home properties used by the primary mortgagor to secure the refinancing. The NMRC would then issue long term bonds secured by the underlying properties. One of the targeted counterparties is the pension fund. The Nigerian pension industry is a fledgling industry that took off in 2004 (PENCOM, 2009) from the ashes of the failed defined benefit scheme in operation before then (Ahmad, 2009). Within a space of 10 years to 2013, the contributory pension fund was N3.72 trillion (USD23.25B) (Uko, 2013) including the transition fund of approved existing schemes of about $4 \%$ of the total funds

\section{Non Bank Financial Institutions- Pension Fund}

Total pension asset to GDP ratio in 2013 was $5.7 \%$ based on the rebasing of the GDP in Nigeria to reflect GDP at current prices and the fundamental restructuring of the economy, estimated to leapfrog GDP from \$262B to \$405B (Atuanya, 2013). The actual rebasing figures have now been released at \$507 Billion. In context of other advanced and comparable economies, the Pension fund asset to GDP ratio is typically higher. In the US and UK for example, it is at $108 \%$ and $112 \%$ respectively while that of France and South Africa is at 7\% and 64\% respectively (Tower Watson, 2013) and the estimated in Ghana is 5.9\% (Awuah-Darko, 2010).These results show that there is a link between state of economic development to pension fund assets. With the exception of France, this theme is consistent across all developed countries.

The Nigeria and Ghana experience shows a pension system that is being refreshed and revitalised, Nigeria in 2004 and Ghana in 2007, and the pension fund to GDP ratio indicate consistent growth amongst the two countries. Similarly the ratio confirms the link between pension fund market development and the depth of the capital market development. It is expected that there would be a concurrent development of insurance business; annuities market, life insurance, the corporate and public bond markets, mortgage market, and related infrastructural dependent long term financing market, along with the pension fund market development (Ahmad, 2009)

However, the stringent quantitative limits and investment benchmarks restricting investment in specific asset class and counterparties may constrain the optimal transmission of investible pension funds to the various investment outlets like government bonds (in the three tiers of government), offshore investments, mutual funds, ETF and mortgages, thus starving infrastructural projects requiring long term financing sources. Specifically, there are restrictive clauses that allows only approved existing funds and closed pension funds (PENCOM, 2009) to invest in real estate whereas the open pension funds which constitute the bulk of the funds are prohibited. This resonates the importance of the need for concurrency in multiple policy adaptation to resolution of economic issues. In this context, the national housing program which sits on a three prong strategy- financial deepening of the mortgage market, land acquisition, and housing and construction development, would in part be dependent on the concurrent liberalisation and opening of the pension fund market to achieve a funding handshake with the mortgage market needs. There might be need to align legislation with the global objectives of the initiatives.

\section{Non Bank Financial Institutions: Angels, Private Equity, Business Incubation And Financial Structures}

In particular, most developed economies have unique financing vehicles like the "business angels" which are specialised local financing vehicle to fund typically untested innovation, technology transfer to developing countries, and new business concepts (Martinez, 2003). Statistics indicate that about 2600 angels 
exist in the US and over 60 in the UK, and aside South Africa with about 15 angels, most countries in Africa including Nigeria and Ghana have 2 each (White, 2011). Operationally, business angels are local financing vehicles with the angels actively mentoring and coaching as a support role, to anchor sustainable root for the fledging enterprise aside their equity financial commitment in the business. Most angels recorded in Africa, operate from diaspora (Koutonin, 2013) and cannot be strictly classified as angels but rather venture capitalist and other forms of PE (Shane, 2009). The relevant point however is the disproportionate absence of this critical financing vehicle in Africa and Nigeria in particular.

Strategy and strategic national initiatives should be anchored on the consistency between internal and external environment (Mintzberg, Ahlstrand, \&Lampel, 1998) to optimise opportunities, be it at the corporate level or national level. In North America, accomplished CEO'S and entrepreneurs like Apple CEO, John Scullen, Netscape's Jim Barkdale and Microsoft Paul Allen (Shane, 2009), have cashed out and become angels to support business growth in industries that they are passionate about. In context, developing countries like Nigeria can also encourage accomplished entrepreneurs like Dangote ( Forbes listed Africa's richest man), Adenuga et al (Nsehe, 2013) to form a network of angels to commence this incubation process of financing for new and fledging business which are inhibited by finance, entrepreneurial expertise and management skills. The Nordic experience of guided innovation and entrepreneurship promotion can be instructive (Trondsen, 2012; Toivanen, 2009) and through policy incentives, the right environment can be created to spur appropriate entrepreneurial growth.

Finance remains one of the most significant challenges for new business. Experience, managerial acumen and skill (McCall, 2004) is another challenge for early start-ups. Business angel as a financing vehicle combines the benefits of solution to the two challenges of early start-ups. Business Angels are the oldest, largest and most often used source of outside funds for entrepreneurial firms and accounting for $50 \%$ of PE funding and VC accounting for the balancein North America (Wong, 2010). Kerr, Lerner and Schoar (2010), provide evidence that "Angel-funded start-up companies are less likely to fail than companies that rely on other forms of initial financing. Developing countries should as a matter of strategic national financial development initiative encourage the development of angels as a source of early business financing. The successful candidates becomes feedstock for VC (Shane, 2009,) and bank financing and thus enlarging the scope of business frontiers. The few angels in Africa operates from diaspora ((Koutonin, 2013). Technically, this arrangement cannot satisfy the essence of the financing tool. One of the pungent features of angels is their geographical proximity to the businesses they invest in (Wong, 2010) principally because their mentorship, handholding,learned experience sharing, networking opportunities, marketing support and managerial support roles are key ingredient to the investment and success of the enterprise (Ajagbawa, 2014). The development of angels must therefore be rooted in the local environment to benefit from these non-financial, but critical resources especially for early start ups. The VC on the other hand have no need for geographical proximity because they employ other control mechanisms over their investments including board control, fund staging and protective contract provisions (Berkery, 2007;Gladstone \& Gladstone, 2004). We suggest the registration of accredited angels and a convocation of local angel networks in developing economies to facilitate technological and economic development.

Financing development captures policies and processes that enable financial intermediation and access to finance and complementary enablers to business and economic development. Business incubation as one of such enablers is a "targeted program developed to accelerate the development of entrepreneurial firms through a wide range of business support services" (Klonowski, 2010). It is the business metaphor for the medical situation of the protective support given to a weak baby at birth by incubating the child until strong enough to cope with the real world. Typically, business incubators are places that provide low cost real estate facilities that offers shared premises, capital equipment, shared technical, logistical and support services, and access to finance through the network of angels, VC and others. The typology covers not-for-profit incubators like technology parks, university incubators and governments sponsored community incubators, and profit oriented incubators like private foundations and entrepreneurial centres. The extreme, strictly for profit business incubators are the venture capitalist and other corporate incubators.

\section{Derivatives Market}

It is apparent from our analyses so far that the stage of economic development of a country appears to define the level, variety, maturity, and complementarity of financial products and vehicles available in the market. Derivatives are one such products that reflects the stage of financial depth of a market. Typically, derivatives covers the breadth of credit derivatives, Equity derivatives, Interest rates derivatives, currency (FX) derivatives, Commodity/Energy derivatives and structured product derivatives (ISDA, 2014) and some products are over the counter deal (OTC) while others are exchange traded (ETP). Some of the notional usefulness of derivatives include the transfer and sharing of risks, helping in stabilising prices by the convergence of current and future price levels, facilitating trade by the augmented activities of market participants, and smoothening the risk of participants in the market. 
Some market watchers have expressed grave concern on the health of this financial product over the years and have cautioned on its extensive and unbridled use. Warren Buffet (2002) described derivatives as "financial weapon of mass destruction" on account of the potentially lethal counterparty credit risk exposure, and the risk of internal abuses of value estimation. The unrestricted and unbridled growth of this burgeoning market, estimated by Paul smith (as cited by Washington Blog, 2012) to be approaching \$1.2quadtrillion notional valuefurther exacerbate the worries on this financial product as potentially lethal to world economic health. Bank of international settlement stated a notional value of $\$ 516$ trillion in 2008 (as cited by Simon, 2012), and the counterparty risks of the systemically important financial institutions embroiled in an extensive interconnectedness accelerated the transmission of the contagion of the toxic assets that eventually brought down the market and the world economy to its knees (Basel 3, 2011)

That the derivatives market is beneficial to the economy is not in doubt (Buffet, 2002; Smith, 2012; Simon, 2012). The net size of the derivatives market is estimated at over $\$ 60$ trillion which is about the size of the world GDP (World Bank, 2013). This puts the importance of the market in context and forces attention on its potential danger in the event of market contagion (Buffet, 2002). The events leading to the collapse of Barings Bank, Bear Sterns, Lehman Brothers and others are ready evidence to the potential lethal danger of the financial product and its eventual contagion of the world economy.

It is needless to reinvent the wheel, therefore, its role in broadening the market size and depth readily recommends the product for optimal adoption in strengthening the financial markets of developing countries. The drawbacks of the financial product is being continuously worked on for enhanced efficiency in the market. Basel 3 (2011) for example has further strengthened the controls over counterparty risk exposure by the introduction of the Credit valuation Adjustment (CVA) risk capital charge in addition to the already existing default risk capital charge to accommodate possible deterioration in the credit worthiness of the counterparty. In addition, OTC deals are now required to route their deals through clearing to afford common standard coverage over transactions (Bartlett, 2011).

The Basel 3 (2011) is a progressive and collaborative guidance process for the health of financial markets across the world. Aside from encouraging the adoption by banks of $8 \%$ minimum total capital adequacy plus conservation buffer from 2013, it requires banks to gradually scale up to $10.5 \%$ in 2019 as a measured process of fortifying the capital buffers of financial institution and systems across the world. The Basel 3 (2011) also requires banks to prepare for adoption in 2015 a liquidity coverage ratio which is yet to be released. These developments provideassurance that the level of joint and collaborative controls over the financial markets is increasingly engaging and comforts younger financial markets on the application and use of these financial products as a means of stimulating growth.

Factually, most developing countries have limited derivatives market. For example, in Nigeria the deals are collateralized, short tenured for 90 days and the notional and net market size at \$2B and \$200M respectively (Eco bank). Out of 25 banks operating in Nigeria , 6 play the derivatives market of which only one is a local bank, First bank, and the others international banks. The breadth of the market is small due to; first, the enhanced counterparty credit risk charge, second, the excess over 15\% capital adequacy limitation for trading in derivatives, and third, the trading products are limited to one directional basic asset swap and cross currency interest rate swaps.

To leverage the benefits of this financial product, Nigerian banks would have to strengthen their capital buffer and broaden the breadth and depth of the derivative product range. This would expand and strengthen their balance sheet to take up more transactions, augment market activities, and facilitate better risk sharing. Given the strength and benefit of focus, commodity exchange, that has a comparative alignment with the factor led economy (GEM, 2012) of developing countries (agriculture for example) would be an appropriate point to develop alongside other exchanges like the exchange traded products. This would help promote price stability, enhance income growth of farmers and generate better economic growth. The dysfunctional commodity market in Nigeria is being arranged for privatization and effectiveness (Oteh, 2014).

\section{Financial Stability}

Before the global financial crisis, triggered by default on credit default swaps (CDS) and mortgage backed securities (MBS), there was a general sentiment on the intertwined syndromes of "too big to fail" (Sorkin, 2009) and too big to regulate (ERC, 2010). There are two compelling issues. First, the market deluded itself that size and financial stability often reflected financial development and advancement in the particular industry. The demise of elephant institutions like Bear sterns, AIG, Enron and earlier on, Barings Bank produced new evidence that invalidated the "too big to fail hypothesis. Second, is that market failure has been blamed partly on the failure in the exercise of regulatory oversight and enforcement responsibilities of regulators (Gradinaru, 2009; ERC, 2010).

Evidence thus suggest that financial stability cannot be equated with size and longevity. Anecdotal evidence suggest that the relationship between capital and distress in financial institution is spurious at best. Other qualitative concerns relating to moral hazard and expectation for bailout, management quality and risk 
appetite of the institution are contributory to financial distress and instability in the banking and non-banking financial system (Barrow \&Smalt, 2013). The ERC (2010) suggest that, since no amount of regulation or enforcement can resolve the ethical issues confronting the economy, organisations should be encouraged by concerted efforts to develop and sustain ethical culture where leaders "walk the talk" (ERC, 2010), and where regulators compare and share best practices through a robust communication framework that would help build strong compliance program for institutions and above all, apply the rules of the game consistently and rigorously.

In Nigeria, the FSS 2020 (Financial systems strategy) aimed at accelerating the country's development to a financial hub status in Africa by 2020, and one of the 20 leading economies of the world is quite instructive. At the heart of the strategy is the strengthening of the financial system to entrench financial stability in the system amongst other objectives. In this wise, a financial stability report is produced bi-annually by the central bank of Nigeria as one of the measures to track and steady the pace of financial stability in the country. It has to be said that there has been relative gains in terms of financial stability in the banking system since the inception of the strategy and its follow through efforts.

\section{Policies, Financial Structures And Non Bank Financial Institutions}

According to Liang \& Reichert (2012), non-bank financial institutions may have systemic importance to the overall financial system by virtue of first, the nature of their portfolios, second, the relative size of their portfolios and lastly their business orientation. The continuing decline of net interest spreads (Fitzpatrick, 2012, Bernstein, 2007) associated with traditional banking services encouraged banks to focus on fee income revenues typically from corporate finance services, off balance sheet items like commercial papers, and risk diversification instruments like derivatives (Sundaram\& Willey, 2009), which appears to have equal market appeal to all financial players, non-bank and bank financial institutions alike.

The lines of distinction of the functions of traditional bank financial institutions and non-bank financial institutions have blurred significantly and in the absence of appropriate guidance legislation, and commensurate regulatory scrutiny on the non-bank financial institutions, we are left with bad corporate behaviour which exposes the system to increased risk. (Levine 2005). Commensurate focus is however being put on non-bank financial institutions in the light of recent past experiences in the financial system and the consequences of the interconnectedness contagion that can spring and spread about instantaneously if unchecked.

The historical morphology of the conglomeration of bank and non-bank financial institutions as single operating units exceed the demand of our paper but a point of relevance is that the debate is unlikely to resolve the issue ever. Ennis \&Keister (2010) concludes that "financial crises have a self-fulfilling component and that the bank's operating structure makes them susceptible to runs and so they are innately fragile". Aside potential runs, excessive competition for profits often lead banks to morally hazardous behaviour and excessive risk taking detrimental to its own health and the public (Martin \& Martin, 2009). The moral hazard issue as noted by Casserley, Harle, \& Macdonald (2010) indicates that banks understand that the reward and payoffs of excessive risk taking is privatised when positive, and nationalised when negative. Shareholders and management pocket huge dividends and bonus when excessive profits are declared but citizen's tax funds are used to subsidize bailouts often because the negative risk payoffs are underwritten by the lender of last resort through bailout or by deposit insurance. The moral hazard applies to both universal and specialised financial institutions.

The argument for universal banking include, economies of scale which translates to lower cost structures and better support to the economy (Casserley, Harle, \& Macdonald, 2010). There is also the argument of stronger and diversified portfolio which absorbs trade and financial cycle shocks better. The argument against the universal banking structure is that first, contagion can spread easily, second, reduces the conflict of interest associated with universal banking and finally moderate the extreme power and influence welded by CEO's of universal banks. Be that as it may, it would appear that no particular structure may provide the assurance of a sound financial system than that which is now being entrenched by the Basel 3 (2011) accord.

The Basel 3 accord is predicated on strengthening the capital base of banks and providing a road map of best practices in common reporting standards and treatment of the synthetic products that initiated the last round of financial crises. Therefore, the extent of regulatory control on the basis of the stringent standards of the Basel accord might be the elixir to fostering a solid and sound financial system world-wide. However, Ferran, Moloney et al (2011) noted that there is high probability that stricter controls following crises are usually relaxed on the passage of time. Perhaps a lesson to regulators to keep their eyes on the ball.

The dismantling of the Glass Steagall wall and similar structures around the world which allowed banks and other financial institutions to freely take positions in banking, securities and insurance business is perceived as one of the remote causes of the 2008 economic crisis. The non-bank financial institutions like insurance companies, hedge funds, pension funds, private equities, discount houses, building societies and brokerage firms, collectively, have systemic importance, and the free cross play in the financial industry with corresponding weak regulatory controls heightened the financial crisis. Most financial institutions were using their subsidiaries to circumvent regulatory limits and thus enlarging the systemic risk exposure of the overall 
market, and this systemic abuses went across borders. Using insurance premium as a proxy, the insurance penetration rate, which describes the ratio of insurance premium to GDP, indicates the systemic importance of the non-bank financial institutions in terms of the volume of gross revenue the industry generates. The penetration rates for Japan, UK, and Taiwan is $10.54 \%, 12.45 \%$ and $14.11 \%$ respectively while that of Ghana Nigeria and Uganda are all less than $1 \%$ respectively (KPMG, 2013; ALPEN CAPITAL, 2011). This provides a first level discriminating factor for development, the more developed countries consistently having a higher penetration rate than the less developed countries.

The trend observed merely indicates the size of the penetration rate in the countries and not the nature of relationship per se. The research work of Liang and Reichert (2012) found a negative relationship between non-bank financial institution and economic growth for both developed and developing countries. It believed that the negative results for the developed countries are not justified by the trends but might reflect the lack of adequate regulatory supervision (Liang \& Reichert, 2012) and unacceptable speculative management style of the large non-bank financial institutions which endangered customers' wealth and the financial system. The recent value destruction from the very systemically important non-bank financial institutions might explain this exposition. For the less developed countries, the result is consistent with Cheng and Degryse (2010) which inferred that the industry growth is stultified by a combination of poverty, trust, and fraud.

Nigeria has one of the lowest penetration rates in Africa at 0.6\% (KPMG, 2013; Bangudu, 2013). A combination of poverty, trust, cultural beliefs, lack of expertise and skills, and preference of the large industries like Oil \& Gas for foreign insurers due to lack of local skills and capacity et al, continue to inhibit the growth of the industry (KPMG, 2013). There has however, been gradual growth following several liberalization initiatives in the industry including enhanced capital level, mergers and acquisitions and introduction of bank assurance and micro insurance practices (Braumuller, 2012).

In addition, the government has made compulsory 16 insurance products which only 5 has been adopted by the National Insurance commission for enforcement (KPMG, 2013). These initiatives are meant to stimulate the growth of insurance business in congruence with the preposition that insurance is demandfollowing economic development (Liang \& Reichert, 2012). As the market continue to reshape for growth, few banks have divested its insurance and non-core financial institutions while some like IBTC, UBA, First Bank are consolidating by establishing holding company (hold co) structure and continue to run its insurance and other non-core financial institutions through the hold co vehicle.

Further, the regulators have instituted a firewall separating banking, insurance and capital market operations through the channel of a holding company. The Central Bank of Nigeria (CBN, 2014) released an exposure draft of a holding structure (hold co) with specific control mechanisms of the firewall including; (1) maximum shareholding in a hold co by any single shareholder is restricted to a maximum of 5\%. (2) subsidiaries and partners cannot hold shares in a hold co. (3) Subsidiaries cannot hold shares in other subsidiaries of the hold co. (4) The hold co will return its license to the CBN if for six continuous months it failed to hold controlling interest in the bank financial institution in the hold co. (5) hold co can only provide shared services to its subsidiaries upon the clearance and approval of the CBN, and approval of the subsidiary board in areas as human capital, risk management, and control and compliance, and (6)hold co cannot interfere in the normal operations of any subsidiary.

The exposure draft also requires that at least one member of each board of the subsidiaries must be a person versed in the theory and practice of that area of business. These firewall controls are expected to limit the extent and intricacies of financial dealings outside the main competencies of each subsidiary and reduce insiders' abuse. As loft and commendable as these guidance policies are, anecdotally, the level of incestuous relationship amongst subsidiary boards and hold co on the one hand and the breakdown of the agency relationship at the hold co level may compromise the ideals envisaged by the policies as neither auditors nor bank covenant watch dogs (auditors) seem to matter these days (Medland, 2014)

Life insurance is the leading sector of insurance industry in most developed insurance markets (Insurance Europe, 2013). This is however on the decline as customers now have more of short term outlook following the global financial crisis expressed by migration to bank savings account. Chen, Lee \& Lee (2012) and Francois (2013) have listed such factors as savings rate, interest rate, social security, income levels, dependency ratio, life expectancy, religion, demographic factors, education, stock market role, and the structure of the market as impacting on the level of life policy achieved in a country. Su, Chang \& Pan (2013) found a bidirectional relationship between life policy and high income economies while they suggest that non-life policy are likely to be more successful in low income economies. As the impacting factors on life insurance grow, depending on the causality direction, we expect changes in the insurance business, and generally, insurance business grows as income levels appreciates in an economy.

There are dynamic interaction within and outside the insurance business. Chen Lee \& Lee (2012) found that the development of life insurance and the stock market are not complementary but substitute and so we should expect competition of the two variables for investible funds. It is also noted that bank savings account can become a substitute for life insurance policy in an era of uncertainties when customers have a short term 
outlook to the economy. Life policy may also have a positive interaction with bank loans as, anecdotally, life policy can be used as collateral in obtaining bank loan. And on the investment side, insurance companies and pension fund have similar investment profiles and general outlook is asset structuring.

Back in Nigeria, both bank and non-bank financial institutions have gone through a process of internal self-regulation, albeit at the nudging of the regulators. The number of banks have reduced from 89 in 2005 to 21 in 2014 through willing and unwilling mergers and acquisition. Insurance companies have also reduced through the same process to 59. Minimum capital of banks and insurance companies were increased from $\$ 12.5 \mathrm{~m}$ and $\$ 1 \mathrm{~m}$ (CBN, NAICOM, 2014) to $\$ 156.25 \mathrm{~m}$ and $\$ 62.5 \mathrm{~m}$ (composite insurance business) respectively by 2006 .

The emerging financial institutions from the mergers were thus capacitated for larger ticket deals in the leading sectors of the economy like the oil and gas and telecoms, owning to their new scale, and this may be an impetus for a new wave of mergers. This new impetus may be compelling now that local banks have had a taste of the high capital and most profitable sector of the oil and gas which was previously dominated by foreign banks. The financial institutions are scaling up their institutions in terms of human capital skill and information technology to deal with both local and international market challenges. The link between the enhanced scale of the banking sector and the economy is evidently positive and playing out in GDP growth and the commensurate growth in key operating indices of the financial institutions over the last few years.

\section{Foreign Direct Investment (Fdi), Liberalization \& Infrastructure}

One of the stylized benefits of scale in the banking industry is decreasing cost of operations. The cost of doing business transmits directly to the cost of capital (ECB, 2009), and it's a major determinant of foreign direct investment as worldwide capital flows will continue to reallocate capital for better efficiency across markets. Essentially, the business environment and the complementary resource support it provides will determine the cost of doing business in any country and eventually the inflow of capital (Jarmuzek\& Banerjee, 2009). For example, the human development index measured by children enrolment rate, adult literacy, and mortality rates of children amongst others (UN, 2013) provides evidence of the labour productivity and competitiveness in a country. This and other infrastructural impediments impacts the cost of doing business in an absolute and comparative basis and influences the flow and reallocation of FDI into regions.

There is evidence to support the suggestion that knowledge-based development can neither be a mere happenstance nor have a magical recipe to its achievement. Rather, it reflects from a well-planned program of investment in technical, and social infrastructure including the human skill set (Mansell, Stein Mueller \&Montalvo, 2008).The internet revolution for example has changed the way knowledge is shared, skills learned and technical infrastructure utilised. IT can be a source of competitive development for a company, country or a people subject to its construct, diffusion approach and eventual utilization (Madon, 2000; Avgerou, 2010). Most developments in the financial markets sit on IT and the accompanying social infrastructure, and these developments impact on cost of transaction processing. For example the transaction processing cost per delivery channel is $\$ 0.20, \$ 0.90$, and $\$ 4.0$ via the internet, ATM and branch bank respectively. The migration of an economy to the virtual channels reduces cost of doing business and release resources for economic growth.

Other social infrastructure including the institutional environment; the rule of law, independence of the judiciary, contract enforcement, corporate governance, transparency amongst regulators might be a discriminating consideration for FDI flows. For example, the recent annexation of Crimea by Russia has created uncertainty and instability in the market about the long term business and political outlook in Russia. The crisis is likely to decelerate much needed foreign investments inflows and accelerate capital flight. Indeed, FDI outflows of \$18Billion has been reported for Q1 of 2014 in almost an instantaneous response to the crisis (Flood, 2014; Weafer, 2014), meanwhile S \& P have cut the Russian foreign currency rating a notch above junk status (The Moscow Times, 2014). The continued escalation of the hostilities with Ukraine is likely to cause further deterioration in overall macroeconomic performance. Research evidence also predict that the average scale of production should rise with the quality of contract and law enforcement in a country (Amaral\&Quintin, 2007). Political stability, the rule of law and contract enforcement are all enablers of FDI flows into a country, which in turn stimulate economic growth.

The role of government, from the social infrastructure perspective in terms of rule of law or enabling economic policies, can be critical to economic development. For example most LDE (less developed economies) were encouraged to dismantle economically repressive laws and regime in the late $20^{\text {th }}$ century in order to liberalize the economy from the shackles of inefficiencies. Financial liberalization thus became a stylized restructuring vehicle for most developing countries till date. Financial liberalization (Maria-Lenuta, George, \&Alin, 2013) entails the basket of policy framework covering the extent to which a country exerts influence over interest rates, foreign exchange rate and ceiling on credits and other major monetary and macroeconomic indices in managing the economy. Maria-Lenuta et al (2013) categorises the policy tools into Domestic, covering interest rates, Privatization of government enterprise to reflect efficiency, removing trading rigidities from the stock exchange and opening up the banking space, market determined credit allocation, free capital flows and the independence of the Central Bank while the external policy tools include, freedom to hold 
foreign financial asset, ability to hold and trade freely foreign currencies, and availability of expanded tools like the ADR and GDR to facilitate international stock market trading across border.

The essence of liberalization is to dismantle national borders and globalise (Hamdi, Hakimi\&Djeiessi, 2013) financial trading across border. Ghosh (2005) described financial liberalization as measures that are designed to make the central bank more independent, remove "financial repression" byfreeing interest rates and allowing financial innovation, reduce directed and subsidized credit, as wellas allow greater freedom in terms of external flows of capital in various forms" Maria-Lenuta et al (2013) posits that liberalization helps to reduce cost of capital through the volume of inflows that increase supply of funds relative to demand, helps to integrate the local emerging markets into the global market. Local firms are able to access international funding through ADR and GDR. Financial liberalization facilitate the development and deepening of the financial markets and gravitate towards a more matured market in view of its exposure and dealing with the established international markets. In opening up its market to the vagaries of the international market through liberalization however, policy makers are usually guided by the uniqueness of a particular economy as distinct from others and so specifically apply a combination of well-paced, consistent macroeconomic policies in driving its liberalization initiatives to spur economic development. There is no one size fits all and each LDE must empirically test what regime of liberalization policy works for it.

The evidence of financial liberalization has been mixed. Owusu\&Odhiambo (2012), from a review of liberalization of the Ivory Coast economy, indicated that financial liberalization through interest rates and capital account liberalization tended to have a positive effect on economic growth and market liquidity but with attendant side effect of reduction in credits to the productive sector of the economy. Maria-Lenuta et al (2013) and Henry (2007) are in agreement that liberalization enhances growth, reduce cost of capital and accelerate investments. Owusu\&Odhiambo (2012) in two separate research works on Nigeria and Ivory Coast found that financial liberalization gave impetus to economic growth. However, in Ivory Coast, they discovered that the side effect of financial liberalization included reduction in credit to the productive sector while in Nigeria, liberalization increased savings and deepened financial development. Fowowe (2011) in his review of subSaharan African countries did not notice any savings growth from financial liberalization. Fawowe agreed though that the results cannot be used in isolation as the institutional structures and macro prudential deficiencies in the LDE would require the strengthening of the market structures to make the use of the conclusions more useful.

Financial liberalization became a stylised approach to dismantling the economic rigidities of the LDE countries at the turn of the century. In Nigeria the structural adjustment policy (SAP) was introduced in 1986 which liberalised foreign exchange and interest rates. The results were crippling. Owusu\&Odhiambo (2012) found that in the face of financial deepening, increased savings, investment and economic growth, the rate of credit to businesses declined. This is consistent with their findings in similar research in Ivory Coast. MariaLenuta supports this position that financial liberalization led to reduced credit for small businesses (SME) especially because of fear of low quality at that level of lending. Hamdi, Hakimi\&Djeiassi (2013) found from their research work on Tunisia that financial liberalization led to decrease in bank's credit quality.

Anecdotally, this is consistent with practical field experience. Massive inflow of capital enhanced banks capital and liquidity levels and capacitated the banks to lend. Driven by profitability, lending was often directed to lower end of the market given the saturation level of the upper tier corporate asset class, and so quality tended to decline in due course. The research result by Ghosh (2005) supports this position.

Liberalization has also led to diversion of credit from the real sector of the economy to the speculative sector. Maria-Lenuta et al (2013) noted that with liberalization, LDE have become speculative and competitive. Owusu\&Odhiambo (2012) discovered that credit to the real sector has suffered disproportionately in favour of miscellaneous items which are basically capital account transactions on invisibles. The work also discovered that the gap between the lending and deposit rates have widened significantly from $2.6 \%$ in 1986 to over $8 \%$ in 2005. This wide interest rate gap has the potential for high loan default which could trigger crisis and self-fulfil the banking fragility preposition.

In Nigeria in particular, the relaxation on regulations on foreign exchange and financial asset transfer and tradability, coupled with minimal trade exchange and foreign trade inhibitions triggered the rate of FDI into the country for speculative reasons. Given the reasonable exchange rate regime stability, and in the face of a disproportionately high interest rates compared to the developed markets, most traders simply arbitrage the market. They bring in foreign currency, exchange to local currency, take position in local currency at the local official foreign exchange bid and prepare to play the market. They hold for a short tenor like a week and offload into the market when they perceive pent up demand has driven up exchange rate to assure arbitrage profit. Some simply play the interest swap derivatives and exit contemporaneously with their foreign exchange exit strategy. The relative dominance of foreign portfolio investment to foreign direct investment bears witness to these practices. Foreign direct investment are meant for physical capital investment in new businesses. 
The flows to the real sector has been limited thus defeating the purpose of financial liberalisation in the country. It is not sound economic reasoning to embark on financial liberalization without accompanying controls that would tie the noose and prevent leakages. Indeed, Liberalization can become an anathema where regulatory controls are weak and not up to speed to keep pace with the private sector pace of development and transaction processing know how and capabilities (ERC, 2010).

\section{Conclusion}

We proposed a symphonic flow and interplay between entrepreneurship, finance and economic development as it would appear that there exists some level of interconnectedness of the concepts. We noted that the financial system function is to ease access to finance through the reduction of information and transaction cost hurdles confronted by economic agents. The entrepreneurs, through the support of finance are able to engage in further entrepreneurial activities that boost production and productivity of the economy.

Schumpeter'sinfluence on entrepreneurship was very visible in our review. The concept of creative destruction as a fulcrum on which the entrepreneurship essence stand was analysed. Through creative destruction, entrepreneurs are challenged to innovation which creates changes to existing economic order leading to new production methods. New products and productionmethods coming out of innovation requires fresh funding and we noted that indeed, there was a temporal convergence between the era of evolution of new financial products with new technologies (Van den Berg, 2012)

Entrepreneurship is about creating new businesses by employing the other factors of production. New business create employment, generate economic activities and enhance the frontiers of productivity in the economy. We noted that entrepreneurship is one of the few engagements that maximises the often conflicting objectives of maximising social gains simultaneously along with personal gains in terms of contribution to tax revenue to government, community contribution to other stakeholders and profits and dividends to the owners of the business. We also noted some interesting facts that demographic structures may impact on the level of entrepreneurship achieved in a country (Levesque \&Minniti, 2006). Entrepreneurs would however require funding to be able to generate these benefits.

Specialised financing vehicles like business angels, private equities, and business incubation were discussed. Similarly specialised innovative products like derivatives were also mentioned. Banking and nonbanking financial intermediation were discussed. The transitioning from bank financial intermediation in developing countries to stock market intermediation in developed countries formed part of the review.

Policies, financial structures and infrastructure; social and physical were also discussed as critical to financial development and its influence on economic development. Financial liberalization accentuate the flow of FDI into an economy if policy and structural rigidities are dismantled to encourage investments. Infrastructural; social and physical, challenges are critical success factor for financial development as they are for economic development. Entrepreneurship would definitely sustain better in an economy of strong infrastructural support. There is commonality amongst the tri concepts as it relates to reliance in sophistication of social and physical infrastructural support for success.

The complementarity of policies and structures to the success of financial development to spur economic development was noted. We used the housing policy in Nigeria that depended on the tri pronged strategic approach of mortgage finance, land acquisition, and housing development, to explain the complementarity of policy framework to assure an effective financial system development to spur economic development. The dependence on mobile banking on information technology development is also germane. Note carefully the opportunities coming out of the financial development deployment for entrepreneurial practices.

Financial access is as critical as the products, vehicles and processes of the financial system. The ability to reach a larger number of potential client is important from different perspectives. First is the analogous concept of production in economics, which is said to be incomplete until the product reaches the consumer. Second is the perspective of enlarging the banking space. Third is spurring employment and growth, andlastly is the importance of povertyalleviation by increasing the breadth and depth of the customers that the financial system is able to reach and empower for economic inclusion in the system.

In making a conclusive remark, we maintain that the review focused on the comingling and interaction of the entrepreneurship process with thefinancial development pillars that impacts and or affected by economic development. The syntheses of the literature indicates five important issues; first is the entrepreneurial processes invoked by creative destruction which facilitates new businesses and productivity, employment and economic growth, the second, relates to financial factors considered integral to financial deepening and development. Third, are non-financial factors which are pivotal for the proper intermediation function and funding access facilitation function to occur, which factors share pivotal commonality with economic developmental. Fourth, the interaction between the entrepreneurial process and the financial intermediation function creates economic activities and opportunities that translatestoeconomic development, and lastly is the extent to which the various 
factors comingle in explaining how each of the factors, or a combination of the factors might affect economic development or and indeed, how each factor might affect each other and comingle to impact on economic development.

Throughout, we attempted a dialectical discus, as much as possible, on the entrepreneurial process and how it interacts with finance and economic development. The pillars of financial development were identified; institutional environment, Business environment, financial stability, Banking Financial services, Non-Banking Financial institutions, financial markets, and financial access. The ramifications of each of the pillars was analysed and its interaction on each other discussed while the nexus to economic development remained the focus of the review.

\section{References}

[1]. Abdelbaki, H. H. (2013). Causality relationship between macroeconomic variables and stock market

[2]. development: evidence from Bahrain. The International Journal of Business and Finance Research $\downarrow$ Volume 7 number 12013. Retrieved on March23, 2014 from http://web.a.ebscohost.com/ehost/search/advanced?sid=028f72f2-1f79-40e4-96cc6e71624a77f5\%40sessionmgr4002\&vid=1\&hid=4106

[3]. Acaravci, S.K., Ozturk, I., Acaravci, A. (2009). Financial development and economic growth:Literature

[4]. survey and empirical evidence from sub-Saharan African countries. Retrieved on March 15, 2014 http://www.google.com.ng/url?sa=t\&rct=j\&q=\&esrc=s\&frm=1\&source=web\&cd=3\&ved=0CDcQFjAC\&url=http $\% 3 \mathrm{~A} \% 2 \mathrm{~F} \% 2 \mathrm{Fsaj}$ ems.org\%2Findex.php\%2Fsajems\%2Farticle\%2Fdownload\%2F258\%2F81\&ei=1KcjU8e3NKOb0AXohYDwAg\&usg=AFQjCNE yuWa13EN0YoSrKnka8qYtA2euA

[5]. Acemoglu, D., Robinson, J.A. (2002). The political economy of the Kuznets curve. Review of

[6]. Development Economics, 6(2), 183-203, 2000. Retrieved on April 8, 2014 from http://files.wcfia.harvard.edu/908 jr kuznets.pdf

[7]. Acheampong, I.K., Wiafe, E.A. (2013) foreign direct investment and stock market development:

[8]. Evidence from Ghana. International Journal of Finance and Policy Analysis 5(1): Spring 2013. Retrieved on March 9, 2014 from http://web.a.ebscohost.com/ehost/search/advanced?sid=028f72f2-1f79-40e4-96cc-

6e71624a77f5\%40sessionmgr4002\&vid=1\&hid=4106

[9]. Adam, S. (1776). An inquiry into the nature and causes of the wealth of nations. An electronic

[10]. classics series publication. Edited by Jim Manis (2005). Retrieved on April 29, 2014 from http://www2.hn.psu.edu/faculty/jmanis/adam-smith/wealth-nations.pdf

[11]. Adelakun, O. J. (2010) Financial Sector development and economic Growth in Nigeria. International

[12]. Journal of Economic Development Research and Investment Vol. 1, No 1, April 2010. Retrieved on March 15, 2014r from http://www.icidr.org/ijedri_vol1no1_april2010/Financial\%20Sector\%20Development\%20and\%20Economic\%20Growth\%20in\%20 Nigeria.pdf

[13]. Adenuga, A.O. (2010) Stock Market Development Indicators and Economic Growth in Nigeria (1990-

[14]. 2009): Empirical Investigations. Central Bank of Nigeria Economic and Financial Review Volume 48/1 March 2010. Retrieved on March 14, 2014 from http://www.cenbank.org/Out/2012/publications/reports/rsd/efr2010/Economic \%20and\%20Financial\%20Review\%20Vol\%2048\%20No\%201,\%20March\%202010/Stock\%20Market\%20Indicator s\%20and\%20Economic\%20Growth.pdf

[15]. Adio, W. (2014). Rebased GDP and un-rebased realities. This Day Newspaper, back page. Monday 7

[16]. April, 2014. Vol. 19. No 6922. Can be retrieved from www.thisdaylive.com

[17]. Ahmad, M.K. (2009). Pension Fund Management: Implications for Sound Financial and Economic

[18]. Management. Retrieved on March 28, 2014 from http://www.pencom.gov.ng/index.php/component/content/article?id=171

[19]. Ajagbawa, H.O. (2014) A review of Angel investors in Nigeria: Development of a case study of Global

[20]. Hospital being a presentation at the annual MBAA international academy of finance meeting in Chicago, March 2014

[21]. Ajagbawa, H.O. (2011). Seminar paper on 753-Meac-mergers and acquisitions-deal structure and the

[22]. underpinning cultural issues (a case study of ETI and Oceanic bank merger). Unpublished Seminar paper.

[23]. Akkarapol Sa-ngasoongsong and Satish T.S. Bukkapatnam. (2012). Variable Selection for Multivariate

[24]. Co integrated Time Series Prediction with PROC VARCLUS in SAS $®$ Enterprise Miner ${ }^{\mathrm{TM}} 7.1$ SAS Global Forum 2012. Statistics and data analysis. Retrieved on March 10, 2014 from http://support.sas.com/resources/papers/proceedings12/340-2012.pdf

[25]. Alam, M.M. (2009). Relationship between Interest Rate and Stock Price: Empirical: Evidence from

[26]. Developed and Developing Countries. Vol. 4 No3. March 2009. International journal of business management. Retrieved on April 8, 2014 from http://www.ccsenet.org/journal/index.php/ijbm/article/viewFile/217/177\%20rel='nofollow'

[27]. Al-Mamun, M. (2013). The Effect of Macroeconomic \& Market Specific Dynamics on Stock Market

[28]. Development in Global Growth Generator Countries. Asian Economic and Financial Review. Volume (Year): 3 (2013). Issue (Month): 9 (September). Pages: 1152-1169. Retrieved on March 20, 2014 from http://ideas.repec.org/a/asi/aeafrj/2013p11521169.html

[29]. Alpen Capital (2011). GCC Insurance Industry August 21, 2011. Retrieved on April 19, 2014 from

[30]. http://www.alpencapital.com/downloads/GCC Insurance\%20Final\%20Draft V5.pdf

[31]. Amati, M., Ardavin, J., Fershtman, J. (2004). Challenges to Economic Development in Nigeria.

[32]. Retrieved on March 1, 2014 from http://ocw.mit.edu/courses/sloan-school-of-management/15-875-applications-of-systemdynamics-spring-2004/projects/nigeria.pdf

[33]. Amaral, P.S., Quintin, E. (2007) Financial Intermediation and Economic Development: A Quantitative

[34]. Assessment. Retrieved on March 20, 2014 from http://www.laef.ucsb.edu/pages/conferences/latinamer07/papers/AmaralQuintin.pdf

[35]. AMCON (2010) Asset Management Company of Nigeria Act, 2010. Retrieved on April 9, 2014 from

[36]. http://amcon.com.ng/documents/AMCON_Act_2010-(1).aspx

[37]. Andries, A. M, Cuza, A. L (2009). Importance of capital markets in economy. University of Iaşi,

[38]. Romania. Retrieved on March 18, 2014 from http://www.seap.usv.ro/annals/ojs/index.php/annals/article/viewFile/229/227

[39]. Atuanya, P. (2013). Nigeria's economy largest in Africa as rebasing boosts GDP to \$405bn. Business

[40]. Day. Retrieved on March 28, 2014 from http://businessdayonline.com/2013/12/nigerias-economy-largest-in-africa-as-rebasingboosts-gdp-to-405bn/\#.UzX1QHRwbIU

[41]. Avgerou, C. (2010) Discourses on ICT and Development: Research Article. Information Technologies 
[42]. \& International Development. Vol. 6. No 3. 2010. Retrieved on April 24 , 2014 from http://web.a.ebscohost.com/ehost/pdfviewer/pdfviewer?vid=11\&sid=4cf75e90-f23e-4fa4-bdb595e9cf2cafba\%40sessionmgr4001\&hid=4214

[43]. Awuah-Darko, D. (2010). Impact of pension reform on the capital market. Retrieved on March 28,

[44]. 2014

from

http://books.google.co.uk/books?id=Qnlukx UZQ4C\&pg=PA74\&lpg=PA74\&dq=pension+size+in+ghana\&source=bl\&ots=pxnXo 5QKVS\&sig=h3 gsQqfzILMXJBjbK9WQiZfIYk\&hl=en\&sa=X\&ei=bvw1U WMEaSL0AXUi4FI\&ved=0CEEQ6AEwAw\#v=one page\&q=pension $\% 20$ size $\% 20$ in $\% 20$ ghana\&f=false

[45]. Ayere, S. (2013) MORTGAGES AS A TOOL IN CREATING 500,000 HOUSING UNITS BY 2016: ASO

[46]. National Housing Exhibition \& Conference. SonnieAyere. CEO, Dunn Loren Merrifield. Task Manager for Federal Ministry of Finance/World Bank/IFC MRC Project. APRIL2013. Retrieved on March 26, 2014 from http://www.asoplc.com/resources/downloads/exco/ASO\%20HOUSING\%20CONFERENCE\%20\&\%20EXHIBITION$1 \% 20$ sunny $\% 20$ ayere.pdf

[47]. Babonea, A.M., Joia, R. (2012) Transition to a green economy - a challenge and a solution for the

[48]. world economy in multiple crisis context. Theoretical and Ap plied Economics. Volume XIX (2012), No. 10(575), pp. 105-114. Retrieved on April 9, 2014 from http://web.b.ebscohost.com/ehost/pdfviewer/pdfviewer?vid=3\&sid=d35f635e-95bf-4485-a39928dbc8fdf568\%40sessionmgr113\&hid=117

[49]. Bangudu, O. (2013). Insurance penetration in Nigeria still very low, says FBN Insurance. Retrieved on

[50]. April 19, 2014 from http://www.premiumtimesng.com/business/147261-insurance-penetration-nigeria-still-low-says-fbninsurance.html

[51]. Banker (2012). Banking must be a risky business. Aug 2012, Vol. 162 Issue 1039, p6-6. 1/2p.

[52]. Retrieved on April 8, 2014 from http://web.b.ebscohost.com/ehost/detail?vid=3\&sid=39dd64ad-067d-4da8-893833642c5210df\%40sessionmgr113\&hid=121\&bdata=JnNpdGU9ZWhvc3QtbG12ZQ\%3d\%3d\#db=bth\&AN=78402645

[53]. Barksaas, J.F. (2012) Shaping our financial future. Socio economic impact of mobile financial services.

[54]. Retrieved on April 9, 2014 from http://www.telenor.com/wp-content/uploads/2012/03/Shaping-our-financial-future-final.pdf

[55]. Barna, F., Mura, P. (2010). Capital market development and economic growth: the case of Romania.

[56]. Annals of the University of Petroşani, Economics, 10(2), 2010, 31-42 31. Retrieved on April 3, 2014 from http://web.a.ebscohost.com/ehost/pdfviewer/pdfviewer?vid=6\&sid=ec36439e-5627-45ae-be5e3a98eab49c54\%40sessionmgr4005\&hid=4107

[57]. Barrow, J.M., Smalt, S.W. (2013). A case for banking oversight reform in crisis mitigation.

[58]. Management, and Financial Markets. Volume 8(4), 2013, pp. 11-26, ISSN 1842-3191. Retrieved on February 21, 2014 from http://web.a.ebscohost.com/ehost/search/advanced?sid=028f72f2-1f79-40e4-96cc6e71624a77f5\%40sessionmgr4002\&vid=1\&hid=4106

[59]. Bartlett, R. (2011). Basel III: The corporate hedging debate. September 2011. Retrieved on April 16,

[60]. 2014 from https://mib.rbs.com/docs/MIB/Insight/Regulation-opportunities-and-challenges/Basel-III-the-corporate-hedgingdebate.pdf

[61]. Basel 3 (2011). Basel Committee on Banking Supervision Basel III: A global regulatory framework for

[62]. more resilient banks and banking systems December 2010 (rev June 2011) Bank for International Settlements Communications CH4002 Basel, Switzerland. ISBN print: 92-9131-859-0 ISBN web: 92-9197-859-0. Retrieved on April 14, 2014 from http://www.bis.org/publ/bcbs188.pdf

[63]. Basu, S. (2011). Self-Fulfilling Prophecies. Economics and investment management. Journal of

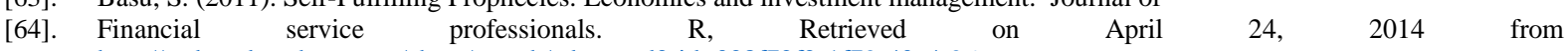
http://web.a.ebscohost.com/ehost/search/advanced?sid=028f72f2-1f79-40e4-96cc6e71624a77f5\%40sessionmgr4002\&vid=1\&hid=4106

[65]. BCG. (2011).The Socio-Economic Impact of Mobile Financial Services. Analysis of Pakistan,

[66]. Bangladesh, India, Serbia and Malaysia. The Boston Consulting Group. Retrieved on March 28, 2014 from http://www.telenor.com/wp-content/uploads/2012/03/The-Socio-Economic-Impact-of-Mobile-Financial-Services-BCG-TelenorGroup-2011.pdf

[67]. Ben-Naceur, S., B.N. Ghazouani, S., Omran, M. (2008). Does stock market liberalization spur financial

[68]. and economic development in the MENA region? Journal of Comparative Economics. Dec2008, Vol. 36 Issue 4, p673-693. 21p. Retrieved on March 7, 2014 from http://web.a.ebscohost.com/ehost/search/advanced?sid=028f72f2-1f79-40e4-96cc6e71624a77f5\%40sessionmgr4002\&vid=1\&hid $=4106$

[69]. Berkery, D. (2008). Raising Venture Capital for the serious Entrepreneur. The McGraw Hill

[70]. Companies.ISBN-13:978-0-07-149602-5

[71]. Bernstein (2007). Regional Banks: Secular, Not Cyclical, Margin Pressure. The impact on bank

[72]. earnings.1/1/2007, p32-37. 6p. Black book- Bernstein Global Wealth management. Retrieved on April 18, 2014 from http://web.a.ebscohost.com/ehost/pdfviewer/pdfviewer?vid=3\&sid=b40aa48d-97c2-41f0-93b4$44 \mathrm{fc} 36 \mathrm{e} 213 \mathrm{cf} \% 40$ sessionmgr4004\&hid $=4206$

[73]. Bertella, M.A., Pires, F.R., Feng, L., Stanley, H.E. (2014). Confidence and the Stock Market: An Agent-

[74]. Based Approach. Published in January 08, 2014. •DOI: 10.1371/journal.pone.0083488. Retrieved on April 8, 2014 from http://www.plosone.org/article/info\%3Adoi\%2F10.1371\%2Fjournal.pone.0083488

[75]. Boateng, F. (2012) Factors Hindering Africa's Development. Feature Article of Wednesday, 15

[76]. February 2012. Retrieved on April 29, 2014 from http://www.ghanaweb.com/GhanaHomePage/features/artikel.php?ID=229892

[77]. BOFID (1991) Banks and other Financial Institutions Decree 1991. Laws of the Federation of Nigeria.

[78]. Retrieved on April 8, 2014 from http://www.nigeria-law.org/BanksAndOtherFinancialInstitutionsDecree1991.htm

[79]. Bofondi, M., Lotti, F. (2006) Innovation in the retail banking industry: The diffusion of credit scoring.

[80]. Review of industrial organization (2006) 28:343-358. Retrieved on April 9, 2014 from http://link.springer.com/article/10.1007/s11151-006-9101-0\#page-2

[81]. Braumüller, P. (2012). Plenary Session 1: Standard-Setting Body Engagement on Financial Inclusion:

[82]. Progress and Challenges. GPFI Conference on Standard-Setting Bodies and Financial Inclusion: Promoting Financial Inclusion through Proportionate Standards and Guidance. International Association of Insurance Supervisors. Basel, 29 October 2012. Retrieved on April 16, 2014 from http://www.iaisweb.org/

[83]. Breido, K., tregub, I. V. (2009). Keynesian theory of consumption: Theoretical and practical aspects.

[84]. Retrieved on April 3, 2014 from http://www.freit.org/WorkingPapers/Papers/PoliticalEconomy/FREIT487.pdf

[85]. Brunnermeier, M.K., Pedersen, L.H. (2009). Market Liquidity and Funding Liquidity. The Review of 
Entrepreneurship, Financial, And Economic Development: A Literary Review

[86]. Financial Studies / $\quad$ v 22 n 6 2009. Retrieved on April 15, 2014 from

http://pages.stern.nyu.edu/ lpederse/papers/Mkt Fun Liquidity.pdf

[87]. Buffet, W. (2002). Derivatives: Chairman's statement-page 13-15. Berkshire Hathaway incorporated.

[88]. 2002 Annual report. Retrieved on March 31, 2014 from http://www.berkshirehathaway.com/2002ar/2002ar.pdf

[89]. Buffet, W. (Gurufocus) (2014). On stock Valuation relative to the US GNP. Retrieved on March 20,

[90]. 2014 from http://www.gurufocus.com/stock-market-valuations.php

[91]. Bundala, N.N. (2012). Economic Growth and Human Development; A Link Mechanism: An Empirical

[92]. Approach. Retrieved on $\quad$ March $\quad 26, \quad 2014$ from https://www.academia.edu/1760696/ECONOMIC GROWTH_AND_HUMAN_DEVELOPMEN_A_LINK MECHANISM_AN_E MPIRICAL APPROACH

[93]. Burgess, K., Grant, J., Demos, T. (2014). Nigerian Stock Market and the State of IPO's. Category:

[94]. Public Offers Private Placements. Retrieved on March 29, 2014 from http://www.proshareng.com/news/15531

[95]. Carlsson, B (2009). New knowledge: the driving force of innovation, entrepreneurship, and economic

[96]. development. Paper to be presented at the Summer Conference 2009 on CBS - Copenhagen Business School, SolbjergPlads 3 DK2000 Frederiksberg, DENMARK, June 17 - 19, 2009. Retrieved on April1, 2014 from http://www2.druid.dk/conferences/viewpaper.php?id=6069\&cf=32

[97]. Casserley, D., Härle, P., Macdonald, J. (2010). Should commercial and investment banking be

[98]. separated? The historical background to the current debate. Mckinsey\& Company. Retrieved on April 18, 2014 from http://www.mckinsey.com/App_Media/Reports/Financial_Services/Commercial_and_Investment_Banking.pdf

[99]. CBN. (2012). National Financial Inclusion strategy: financial inclusion in Nigeria. Issued by the Central

[100]. Bank of Nigeria. Retrieved on April 10, 2014 from www.microfinancegateway.org/../Central\%20Bank\%20of\%20Nigeria N

[101]. CBN. (2013) OVERVIEW OF THE NIGERIA MORTGAGE REFINANCE COMPANY (NMRC). A Central Bank

[102]. of Nigeria Publication. Retrieved on March $26, \quad 2014$ http://www.cenbank.org/Out/2014/CCD/Overview\%20of\%20the\%20Nigeria\%20Mortgage\%20Refinance\%20Company.pdf

[103]. Chemmanur, T.J., Fulghieri, P. (2014) Entrepreneurial Finance and Innovation: An Introduction and

[104]. Agenda for Future Research. The Review of Financial Studies / v 27 n 1 2014. Published by Oxford press. Retrieved on April 27, 2014 from http://rfs.oxfordjournals.org/content/27/1/1.full.pdf + html

[105]. Chen, P., Lee, C.C., Lee, C.F. (2012). How does the development of the life insurance market affect

[106]. economic growth? Some international evidence. Journal of International Development DOI: 10.1002/jid.1765. J. Int. Dev. 24, 865893. Retrieved on April 12, 2014 from http://web.a.ebscohost.com/ehost/resultsadvanced?sid=4723f20e-53b9-4e5d-825da95a827566d3\%40sessionmgr4001\&vid=7\&hid=4212\&bquery=financial+development+AND+economic +growth\&bdata=JmRiPW J0aCZ0eXB1PTEmc210ZT1laG9zdC1saXZ1

[107]. Chima, O. (2014). \$10billion of Nigeria's external reserves is hot money. P. 36 This Day Newspaper.

[108]. Monday 7 April, 2014. Vol. 19. No 6922. Can be retrieved from http://www.thisdaylive.com

[109]. Croitoru, A. (2012). The Theory of Economic Development: An Inquiry into Profits, Capital, Credit,

[110]. Interest and the Business Cycle (Schumpeter, J.A, 1934), translated from the German by Redvers Opie, New Brunswick (U.S.A) and London (U.K.): Transaction Publishers. A review to a book that is 100 years old. JOURNAL OF COMPARATIVE RESEARCH IN ANTHROPOLOGY AND SOCIOLOGY Copyright $\odot$ The Author(s), 2012 Volume 3, Number 2, Winter 2012 ISSN 2068 - 0317. Retrieved on April 27, 2014 from http://www.oalib.com/search?kw=Alin\%20Croitoru\&searchField=authors

[111]. Cromwell, J.B., Hannan, M.J., Labys, W.C., Terraza, M. (1994). Multivariate Tests for time series

[112]. models. Series: Quantitative Applications in the Social Sciences. Sage publications. ISBN 978-0-8039-5440-3

[113]. Das, D.K., Dutta, C.B. (2013). Global financial crisis and foreign development assistance shocks in

[114]. least developing countries. Journal of economic development volume 38, number 2, June 2013. Retrieved on April 7, 2014 from http://web.a.ebscohost.com/ehost/resultsadvanced?sid=028f72f2-1f79-40e4-96cc6e71624a77f5\%40sessionmgr4002\&vid=2\&hid=4106\&bquery=financial+development\&bdata=JmRiPWJ0aCZ0eXB1PTEmc210ZT 1laG9zdC1saXZ1

[115]. Deloitte (2008). Evolving Models of Retail Banking Distribution Capitalizing on changes in channel

[116]. usage. Retrieved on March 27, 2014 from https://www.deloitte.com/assets/DcomUnitedStates/Local\%20Assets/Documents/us_fsi_CBS_Evolving_Models_may08.pdf

[117]. Dennis, M.A. (2013). Silicon Valley. Encyclopaedia Britannica. Retrieved on March 28, 2014 from

[118]. http://global.britannica.com/EBchecked/topic/544409/Silicon-Valley

[119]. Dietz, M., Reibestein, R., Walter, C. (2008). What's in store for global banking. Mckinsey Quarterly

[120]. 2008 issue 1, p19-23. Retrieved on February 21, 2014 from http://web.a.ebscohost.com/ehost/search/advanced?sid=028f72f2-1f7940e4-96cc-6e71624a77f5\%40sessionmgr4002\&vid=1\&hid=4106

[121]. Dritsaki, C., \&Dritsaki-Bargiota, M. (2006). The causal relationship between stock, credit market and

[122]. economic development: an empirical evidence for Greece. Retrieved on March 19, 2014 from http://www.econbiz.de/Record/thecausal-relationship-between-stock-credit-market-and-economic-development-an-empirical-evidence-for-greece-dritsakichaidoo/10003371073

[123]. ECB (2007). European Central Bank. Finance and growth: a macroeconomic assessment of the

[124]. evidence from a European angle. Retrieved on March 18, 2014 from http://www.ecb.europa.eu/pub/pdf/scpwps/ecbwp787.pdf

[125]. Eco Bank (2014). Interview with the Treasurer of Eco bank Transnational (Nigeria) on the size and

[126]. market dynamics of the derivatives market in Nigeria on April 16, 2014

[127]. Economic Quarterly_-Volume 96, Number 1-First Quarter 2010-Pages 33-58

[128]. Edwards, J.A (2006). Politics, Inflation, and the Mundell-Tobin Effect. North Carolina A\&T State

[129]. University 2006. MPRA-Munich Personal RePEc Archive. Retrieved on April 5, 2014 from http://mpra.ub.unimuenchen.de/36443/1/MPRA paper 36443.pdf

[130]. Ekmekçioğlu, E (2012) the Relationship between Financial Development and Economic Growth in

[131]. Emerging Markets. International Journal of Arts and Commerce Vol. 1 No. 4 September 2012. Retrieved on March, 2014 from www.ijac.org.uk/images/frontImages/gallery/Vol._1_No.4/3.pdf

[132]. Ennis, H.M., Keister, T. (2010).On the Fundamental Reasons for Bank Fragility. Retrieved on April 19,

[133]. 2014 from http://web.a.ebscohost.com/ehost/pdfviewer/pdfviewer?vid=3\&sid=7054ffd0-c28a-40c3-aba1688584588522\%40sessionmgr4005\&hid=4101

[134]. ERC (2010). Too Big to Regulate: Preventing Misconduct in the Private Sector. Ethics Resource Centre

[135]. fellows Program White paper 2010. Retrieved on March 30, 2014 from http://www.ethics.org/resource/too-big-regulate-preventingmisconduct-private-sector 
[136]. Erdogdu, E. (2009). Electricity Demand Analysis Using Cointegration and ARIMA Modelling: A case

[137]. study of Turkey. Energy Market Regulatory Authority, Republic of Turkey. MPRA Paper No. 19099, posted 22. December 2009 06:18 UTC. Retrieved on April 26, 2014 from http://mpra.ub.uni-muenchen.de/19099/

[138]. Everett, T., Ishwaran, M., Ansaloni, G.P., Rubin, A. (2010). Economic Growth and the Environment.

[139]. Defra Evidence and Analysis Series, Paper 2. Retrieved on April 1, 2014 from https://www.gov.uk/government/uploads/system/uploads/attachment_data/file/69195/pb13390-economic-growth-100305.pdf

[140]. Ezekiel (47:9) Water flowing from the temple. English standard version. Retrieved on April 22, 2014

[141]. from http://www.biblegateway.com/passage/?search=Ezekiel+47\&version=ESV

[142]. Fairlie, R.W., Krashinsky, H.A, (2012). Liquidity constraints, household wealth, and entrepreneurship

[143]. revisited.Review of Income and Wealth Series 58, Number 2, June 2012. DOI: 10.1111/j.1475-4991.2011.00491.x. Retrieved from http://content.ebscohost.com/pdf27_28/pdf/2012/2GZ/01Jun12/74712963.pdf?T=P\&P=AN\&K=74712963\&S=R\&D=bth\&EbscoCo ntent=dGJyMNXb4kSeqK84y9f3OLCmr0yeprNSsqm4Ta\%2BWxWXS\&ContentCustomer=dGJyMOzpr0yxrLNPuePfgeyx44Dt6f IA

[144]. Fayissa, B., Nsiah, C. (2013).The Impact of Governance on Economic Growth in Africa The Journal of

[145]. Developing Areas, Volume 47, Number 1, spring 2013, pp. 91-108 (Article) Published by Tennessee State University College of Business $\quad$ DOI: $\quad 10.1353 /$ jda.2013.0009. $\quad$ Retrieved on April $\quad 30, \quad 2014 \quad$ from http://web.a.ebscohost.com/ehost/pdfviewer/pdfviewer?vid=3\&sid=7054ffd0-c28a-40c3-aba1688584588522\%40sessionmgr4005\&hid=4101

[146]. Ferran, Eilís, et al. The Regulatory Aftermath of the Global Financial Crisis. 1st ed. Cambridge:

[147]. Cambridge University Press, 2012. Cambridge Books Online. Web. http://dx.doi.org/10.1017/CBO9781139175821

[148]. Fitzpatrick, D. (2012). Low Rates Pummel Banks Borrowers Benefit, but Industry Lending Profits Hit

[149]. Lowest Level in Three Years. The wall Street Journal, October 22, 2012. Retrieved on April 18, 2014 from http://online.wsj.com/news/articles/SB10001424052970203400604578072803523271848

[150]. Flood, C. (2014). Crimea causes Russia investment crises. Investment strategy. Retrieved on April 11,

[151]. 2014 from http://www.ft.com/intl/cms/s/0/9e3e6dd2-b4df-11e3-9166-00144feabdc0.html\#axzz2ybDZxmJT

[152]. Foreign Exchange (Monitoring and Miscellaneous Provisions) Act Chapter F34 (Decree No 17 of

[153]. 1995). Laws of the Federation of Nigeria. Retrieved on April 8, 2014 from http://www.nigerialaw.org/Foreign\%20Exchange\%20(Monitoring\%20and\%20Miscellaneous\%20Provisions)\%20Act.htm

[154]. Fowowe, B. (2011). Financial liberalization in sub-Saharan Africa: what do we know? Journal of

[155]. Economic Surveys. doi: 10.1111/j.1467-6419.2011.00689.x. Retrieved on April 12, 2014 from http://web.a.ebscohost.com/ehost/detail?vid=5\&sid=4723f20e-53b9-4e5d-825da95a827566d3\%40sessionmgr4001\&hid=4212\&bdata=JnNpdGU9ZWhvc3QtbGl2ZQ\%3d\%3d\#db=bth\&AN=86693635

[156]. François, O.J. (2013). The relationship between insurance and economic development: 85 empirical

[157]. papers for a review of the literature. Risk Management \& Insurance Review, 10981616, Mar2013, Vol. 16, Issue 1. Retrieved April 12, 2014 from http://web.a.ebscohost.com/ehost/detail?vid=5\&sid=4723f20e-53b9-4e5d-825da95a827566d3\%40sessionmgr4001\&hid=4212\&bdata=JnNpdGU9ZWhvc3QtbG12ZQ\%3d\%3d\#db=bth\&AN=86693635

[158]. Frepp, J. (2013). Better than cash: reflections on the journey towards cashlite: from a practitioner.

[159]. Retrieved on March 27, 2014 from http://bankingbeyondbranches.com/tag/alternative-delivery-channels/

[160]. GekkoQuant. (2012). Statistical Arbitrage - Correlation vsCointegration what is statistical arbitrage.

[161]. Retrieved on April 26, 2014 from http://gekkoquant.com/2012/10/21/statistical-arbitrage-correlation-vs-cointegration/

[162]. GEM (2012). Global Entrepreneurship Monitor. 2012 Report; p 18, chapter 2. Retrieved on August 3,

[163]. 2013 from http://www.Gemconsortium.org/Reports

[164]. Ghosh, J. (2005). The Economic and Social Effects of Financial Liberalization: A Primer for Developing

[165]. Countries. Economic and social affairs. DESA Working Paper No. 4 ST/ESA/2005/DWP/4. Retrieved on April 22, 2014 from http://www.un.org/esa/desa/papers/2005/wp4_2005.pdf

[166]. Ghosh, S. (2007) Does Financial Liberalization Lower Problem Loans in Banks? Government of India -

[167]. Economic Analysis \& Policy. Economic Notes, Vol. 36, No. 2, pp. 171-188, July 2007. Social science research network. Retrieved on April 22, 2014 from http://papers.ssrn.com/sol3/papers.cfm?abstract_id=1082613

[168]. Ghossoub, E.A., Reed, R.R. (2013). The Stock Market, Monetary Policy, and Economic Development.

[169]. Southern Economic Journal 2013, 79(3), 639-658. DOI: 10.4284/0038-4038-2011.202. Retrieved on March 7, 2014 from http://web.a.ebscohost.com/ehost/search/advanced?sid=028f72f2-1f79-40e4-96cc6e71624a77f5\%40sessionmgr4002\&vid=1\&hid=4106

[170]. Gladstone, D., Gladstone, L. (2004). Venture Capital Investing. The complete Handbook for investing

[171]. in private businesses for outstanding profits. Financial Times Prentice Hall. New Jersey. ISBN 0-13-101885-X

[172]. Gloede, O., Rungruxsirivorn, O. (2013). Local Financial Development and Household Welfare: Micro

[173]. evidence from Thai Households. Emerging Markets Finance \& Trade / July-August 2013, Vol. 49, No. 4, pp. 22-45. Retrieved on April 7, $2014 \quad$ from http://web.a.ebscohost.com/ehost/resultsadvanced?sid=028f72f2-1f79-40e4-96cc6e71624a77f5\%40sessionmgr4002\&vid=2\&hid=4106\&bquery=financial+development \&bdata=JmRiPWJ0aCZ0eXB1PTEmc210ZT 1laG9zdC1saXZ1

[174]. Goldsmith, R.W. (1959). Financial structure and development as a subject for international

[175]. comparative study. Chapter. Pages in book: (p. 114 - 123). Retrieved on April 14, 2014 from http://www.nber.org/chapters/c4417.pdf

[176]. Gomme, P. (2005). The Economy: Why Policymakers Should Relax-And Learn to Respect the Stock-

[177]. Market Bubble. US Banker. P.41 \& 47. Retrieved on March 9, 2014 from http://web.a.ebscohost.com/ehost/search/advanced?sid=028f72f2-1f79-40e4-96cc6e71624a77f5\%40sessionmgr4002\&vid=1\&hid=4106

[178]. Gradinaru, C. (2009) The Importance of Using Bank Supervision and Regulation to Promote Market

[179]. Discipline of Banks. Retrieved on February 21, 2014 from http://web.a.ebscohost.com/ehost/search/advanced?sid=028f72f2-1f7940e4-96cc-6e71624a77f5\%40sessionmgr4002\&vid=1\&hid=4106

[180]. Grealish, A., Mohr, S., Rutstein, C., Schwarz, J., Storz, N., Urban, M. (2011). Winning after the storm.

[181]. Global payment 2011.Boston Consulting Group report. Retrieved on April 9, 2014 from https://www.bcg.com/documents/file71194.pdf

[182]. GSMA (2014) GSMA Mobile Money: Mobile for development intelligence. Retrieved on March 24,

[183]. 2014 from https://mobiledevelopmentintelligence.com/sectors/2-mobile-money?gclid=CImWq4e0q70CFWfLtAodNAQArw 
[184]. Hamdi, H., Hakimi, A., Djelassi, M. (2013). Did financial liberalization lead to bank fragility? Evidence

[185]. from Tunisia. The International Journal of Business and Finance Research VOLUME 7 NUMBER 5 2013. Retrieved on April 12, 2014 from http://web.a.ebscohost.com/ehost/resultsadvanced?sid=4723f20e-53b9-4e5d-825da95a827566d3\%40sessionmgr4001\&vid=7\&hid=4212\&bquery=financial+development+AND+economic+growth\&bdata=JmRiPW J0aCZ0eXB1PTEmc210ZT1laG9zdC1saXZ1

[186]. Henry, P.B. (2007). Capital Account Liberalization: Theory, Evidence, and Speculation. NBER Working

[187]. Paper No. 12698. NATIONAL BUREAU OF ECONOMIC RESEARCH. 1050 Massachusetts Avenue Cambridge, MA 02138 Retrieved on April 22, 2014 from http://www.nber.org/papers/w12698

[188]. Hoi, L.Q., Hoi, C.M. (2013). Financial Sector Development and Income Inequality in Vietnam Evidence

[189]. at the Provincial Level. Journal of Southeast Asian Economies P. 263-277 Vol. 30, No. 3, December 2013. Retrieved on April 7, 2014 from http://web.a.ebscohost.com/ehost/resultsadvanced?sid=028f72f2-1f79-40e4-96cc6e71624a77f5\%40sessionmgr4002\&vid=2\&hid=4106\&bquery=financial+development \&bdata=JmRiPWJ0aCZ0eXB1PTEmc210ZT 1laG9zdC1saXZ1

[190]. Horng, M., Chang, Y., Wu, T. (2012). Does insurance demand or financial development promote

[191]. economic growth? Evidence from Taiwan. Applied Economics Letters, 2012, 19, 105-111. Retrieved on April 13, 2014 http://web.a.ebscohost.com/ehost/resultsadvanced?sid=4723f20e-53b9-4e5d-825da95a827566d3\%40sessionmgr4001\&vid=7\&hid=4212\&bquery=financial+development+AND+economic+growth\&bdata=JmRiPW J0aCZ0eXB1PTEmc210ZT1laG9zdC1saXZ1

[192]. IMF financial inclusion. Retrieved on April 15, 2014 from

[193]. http://www.mature-sex.gsma.com/mobilefordevelopment/wp-content/uploads/2012/06/imfworkingpaperictfinancialinclusion.pdf

[194]. Insurance Europe (2013) Retrieved on April 19, 2014 from

[195]. http://www.insuranceeurope.eu/uploads/Modules/Publications/eif-2013-final.pdf

[196]. Internet World Stats (2013). Internet usage and population statistics. Retrieved on March 30, 2014

[197]. from http://www.internetworldstats.com/stats1.htm

[198]. ISDA (2014). Asset Classes. Retrieved on March 31, 2014 from https://www2.isda.org/asset-classes/

[199]. Israel, G.D. (2009). Determining sample size. University of Florida, IFAS extension. Retrieved on April

[200]. 29, 2014 from https://edis.ifas.ufl.edu/pdffiles/PD/PD00600.pdf

[201]. Jarmuzek, M., Benerjee, B. (2009). Anatomy of Regional Disparities in the Slovak Republic. IMF

[202]. Working paper, European Department. Retrieved on April 11, 2014 from http://books.google.com.ng/books?id=6rDJAC6B3WAC\&pg=PA12\&lpg=PA12\&dq=why+reallocate+fdi+to+regions\&source=bl\& ots=NHFNPQPCsn\&sig=OodC Xf-

3ysiyiur8aD2sfBzSbE\&hl=en\&sa=X\&ei=MRhIU9iwOMSa1AXU1oG4Cg\&ved=0CFYQ6AEwCQ\#v=onepage\&q=why\%20reallo cate $\% 20 \mathrm{fdi} \% 20$ to $\% 20$ regions $\& \mathrm{f}=$ false

[203]. Kagochi, J.M., Nasser, M.A., Kebede, E. (2013) Does financial development hold the key to economic

[204]. growth? The case of sub-Saharan Africa. P. 61-79. Volume 47 No. 2 Fall 2013. The journal of developing areas. Retrieved on April 8, 2014 from http://web.a.ebscohost.com/ehost/resultsadvanced?sid=028f72f2-1f79-40e4-96cc6e71624a77f5\%40sessionmgr4002\&vid=2\&hid=4106\&bquery=financial+development \&bdata=JmRiPWJ0aCZ0eXB1PTEmc210ZT 1laG9zdC1saXZ1

[205]. Kar, S., Mandal, K. (2014). Re-Examining the Finance-Growth Relationship for a Developing Economy:

[206]. A Time Series Analysis of Post-Reform India. The Journal of Developing Areas, Volume 48, Number 1, Winter 2014, pp. 83-105 (Article) Published by Tennessee State University College of Business. DOI: 10.1353/jda.2014.0017. Retrieved on April 12, 2014 from 6e71624a77f5\%40sessionmgr4002\&vid=1\&hid $=4106$

http://web.a.ebscohost.com/ehost/search/advanced?sid=028f72f2-1f79-40e4-96cc-

[207]. Kemal, A.R., Qayyum, A., \&Hanif, M.N., (2008). Financial Development and Economic Growth:

[208]. Evidence from a Heterogeneous Panel of High Income Countries. Online: The Lahore Journal of Economics 12:1 P. 1-34. Retrieved on March 18, 2014 from http://mpra.ub.uni-muenchen.de/10198/1/MPRA_paper_10198.pdf

[209]. Kerr, W.R., Lerner, J., and Schoar, A. (2010) The Consequences of Entrepreneurial Finance: Evidence

[210]. from Angel Financings. Retrieved on April 11, 2014 from http://www.mit.edu/ aschoar/KLS-Angels-June2011.pdf

[211]. Kerr, W.R., Nanda, R. (2009). Financing Constraints and Entrepreneurship. Harvard Business School.

[212]. Retrieved on April 27, 2014 from http://www.hbs.edu/faculty/Publication\%20Files/10-013.pdf

[213]. Keynes, J. M. (1936). The General Theory of Employment, Interest and Money. Book III: Chapter 8.

[214]. The Propensity to Consume: I. Retrieved $\quad$ on $\quad$ April https://www.marxists.org/reference/subject/economics/keynes/general-theory/ch08.htm

[215]. Kim, D., Lin, S., Suen, Y. (2012). The simultaneous evolution of economic growth, financial

[216]. development, and trade openness. The Journal of International Trade \& Economic Development. Vol. 21, No. 4, August 2012, 513537. Retrieved on March 9, 2014 from http://web.a.ebscohost.com/ehost/search/advanced?sid=028f72f2-1f79-40e4-96cc6e71624a77f5\%40sessionmgr4002\&vid=1\&hid=4106

[217]. Kim, D., Lin, S. (2013). Interrelationships among banks, stock markets and economic growth: an

[218]. empirical investigation. Applied Economics. Nov2013, Vol. 45 Issue 31, p4385-4394. 10p. Retrieved on March 9, 2014 from http://web.a.ebscohost.com/ehost/search/advanced?sid=028f72f2-1f79-40e4-96cc6e71624a77f5\%40sessionmgr4002\&vid=1\&hid=4106

[219]. King, R.G., \& Levine, R. (1993). Finance and Growth: Schumpeter Might Be Right*. The Quarterly

[220]. Journal of Economics (1993) 108 (3): 717-737. doi: $0.2307 / 2118406$. Retrieved on March 18, 2014 from http://www.oxfordjournals.org/subject/economics/nobel prize.html

[221]. Kizys, R., Pierdzioch, C. (2010) Banks, Risk, and the Business Cycle: An Analysis Based on Real-Time

[222]. Data. 2010, Banking and Finance Review. Retrieved on March 10, 2014 from http://web.a.ebscohost.com/ehost/search/advanced?sid=028f72f2-1f79-40e4-96cc6e71624a77f5\%40sessionmgr4002\&vid=1\&hid=4106

[223]. Klonowski, D. (2010) Business Incubation and its connection to Venture capital. Douglas Cummings

[224]. (editor) Venture capital: Investment strategies, structures, and policies. KOLB series in Finance. John Wiley. ISBN 978-0-47049914-6

[225]. Kolapo, F.T., Adaramola, A.O., (2012) The Impact of the Nigerian Capital Market on Economic

[226]. Growth (1990-2010). Vol1. No1 (2012). International Journal of Developing Societies Retrieved on March 19, 2014 from http://wscholars.com/index.php/ijds/article/view/02

[227]. Kotter, J.P. (2012) Leading change. P.153-166 ( anchoring new approaches in the culture) Harvard 
[228]. Business review Press. ISBN 978-1-4221-8643-5

[229]. Koutonin, M.R. (2013). Top Business Angels and Investors in Africa. Retrieved on March 30, 2014

[230]. from http://www.siliconafrica.com/author/admin/

[231]. KPMG (2013). Africa Banking Industry Customer Satisfaction Survey April 2013. Retrieved on March 27, 2014 from http://www.kpmg.com/NG/en/IssuesAndInsights/ArticlesPublications/Documents/Africa\%20Banking\%20Industry\%20Customer\% 20Satisfaction\%20Survey\%20-\%20\%202013.pdf

[232]. KPMG (Thunstrom\& Miles) (2013). Financial services sin Africa. Banking, Insurance and Private

[233]. Equities. Retrieved on April 19, 2014 from https://www.kpmg.com/Africa/en/IssuesAndInsights/ArticlesPublications/Documents/KPMG\%20Financial\%20Services\%20in\%20Africa.pdf

[234]. Kpodar Mobile Phones and development. Retrieved on April 15, 2014 from

[235].

https://mises.org/books/economic_development_robbins.pdf/www.google.com.ng/url?sa=t\&rct=j\&q=\&esrc=s\&frm=1\&source=we $\mathrm{b} \& \mathrm{~cd}=10 \& v e d=0 \mathrm{CHMQFjAJ} \& u r l=\mathrm{http} \% 3 \mathrm{~A} \% 2 \mathrm{~F} \% 2 \mathrm{Fwww}$. rei.unipg.it\%2Frei\%2Farticle\%2Fdownload\%2F75\%2F85\&ei=1 KcjU8 e3NKOb0AXohYDwAg\&usg=AFQjCNGMm_L2pXyCnvzHrQKawtmgjTczAw

[236]. Kumari, J., Mahakud, J (2012) Relationship between stock prices, exchange rate and the demand for

[237]. money in india. Economics, Management, and Financial Markets. Volume 7(3), 2012, pp. 31-52, ISSN 1842-3191 Retrieved on March 15, 2014 from http://connection.ebscohost.com/c/articles/84270865/relationship-between-stock-prices-exchange-ratedemand-money-india

[238]. Laeven, L, Levine, R, Michalopoulos, S. (2010) Financial Innovation and Endogenous Growth.

[239]. Retrieved on March 18, 2014 from http://ideas.repec.org/p/ads/wpaper/0097.html

[240]. Lagos State. (2012). Lagos state Investor Handbook: A Guide to Business and Investment.

[241]. www.lagosstate.gov.ng. Retrieved on March 26, 2014 from http://gemsnigeria.com/wordpress/wp-content/uploads/2012/12/LagosState-Investor-Handbook Finals-2.pdf

[242]. Lee Kuan Yew (2000). From Third World to First World. The Singapore Story: 1965-2000. Singapore

[243]. and the Asian Economic boom. First edition. ISBN 0-06-019776-5

[244]. Lerner, J., Hardymon, F., Leamon, A. (2012). Venture capital \& Private equity: A casebook. Fifth

[245]. edition. ISBN 978-0-470-65-91-2

[246]. Levesque, M. Minniti, M. (2006) the effect of aging on entrepreneurial behaviour. Journal of

[247]. Business venturing. Mar2006, Vol. 21 Issue 2, p177-194. 18p. DOI: 0.1016/j.jbusvent.2005.04.003rch 2006, Pages 177-194. Retrieved from http://web.b.ebscohost.com/ehost/detail?vid=19\&sid=2bd4e11b-2267-4a11-918ae807a6195b0f\%40sessionmgr112\&hid=128\&bdata=JnNpdGU9ZWhvc3QtbGl2ZQ\%3d\%3d\#db=bth\&AN=19687524

[248]. Levine, R. (2005) Finance and Growth: Theory and Evidence. NBER Working Paper No. 10766. Issued

[249]. in September 2004. NBER Program(s): CF EFG IFM. Retrieved on March 18, 2014 from http://www.nber.org/papers/w10766

[250]. Levine, R (2014) Stock market: A spur to economic growth. Retrieved on March 12, 2014 from

[251]. http://faculty.haas.berkeley.edu/ross_levine/Papers/1997_Mag_ASXP_Spur\%20to\%20Growth.pdf

[252]. Levine, R., Schmukler, S. (2005). Internationalization And Stock Market Liquidity," Review of Finance,

[253]. 2006, v10 (Mar), 153-187. NBER Working Paper No. 11894 Issued in December 2005. Retrieved on April 15, 2014 from http://www.nber.org/papers/w11894

[254]. Levitov, M. (2013). Nigeria Exchange to Lure 500 Companies in Next Five Years. Retrieved on March

[255]. 29, 2014 from http://www.bloomberg.com/news/2013-10-20/nigeria-exchange-to-lure-500-companies-in-next-five-years.html

[256]. Liang, H., Reichert, A.K. (2012). The impact of banks and non-bank financial institutions on economic

[257]. growth. The Service Industries Journal. Vol. 32, No. 5, April 2012, 699-717. Retrieved on April 15, 2014 from http://web.a.ebscohost.com/ehost/search/advanced?sid=028f72f2-1f79-40e4-96cc6e71624a77f5\%40sessionmgr4002\&vid=1\&hid=4106

[258]. Lim, P.J. (2012). The Economy and Stocks: A Big Disconnect. The New York Times, December 15,

[259]. 2012. Retrieved on March 26, 2-14 from http://www.nytimes.com/2012/12/16/your-money/the-economy-and-the-stock-market-abig-disconnect.html? $\mathrm{r}=0$

[260]. Lisson, T., Gasteiger, E. (2007). Forecasting GDP growth. Retrieved on April 26, 2014 from

[261]. http://homepage.univie.ac.at/robert.kunst/070107_efc.pdf

[262]. Liu, X., Sinclair, P. (2008). Does the linkage between stock market performance and economic

[263]. growth vary across Greater China? Applied Economics Letters, 2008, 15, 505-508. Retrieved on Marc23, 2014 from http://web.a.ebscohost.com/ehost/search/advanced?sid=028f72f2-1f79-40e4-96cc6e71624a77f5\%40sessionmgr4002\&vid=1\&hid=4106

[264]. LLSV (2000). (La Porta, R., Lopez-de-Silanes, F., Shleifera, A., Vishny R. 2000). Investor Protection and

[265]. Corporate Governance Retrieved on April 5, $2014 \quad \underline{\text { http://faculty- }}$ research.edhec.com/mailing/drd/flds/investorprotectionandcorporategovernance.pdf and http://web.ebscohost.com/ehost/detail?sid=214d6aba-b32f-48f5-8c39-

[266]. LLSV (2007). (La Porta, R., Lopez-de-Silanes, F., Shleifera, A., Vishny R. 2007). The Economic

[267]. Consequences of Legal Origins. Journal of Economic Literature. Stanford Graduate School of Business. 518 Memorial Way. Retrieved on April 14, 2014 from http://papers.ssrn.com/sol3/papers.cfm?abstract id=1028081

[268]. Lo, A.W. (2007). Efficient market hypothesis. The New Palgrave: A Dictionary of Economics, Second

[269]. Edition, 2007. New York: Palgrave McMillan. Retrieved on April 9, 2014 from http://web.mit.edu/alo/www/Papers/EMH Final.pdf

[270]. LSE. (2014). Statistics on new issues: IPO. London Stock Exchange. Retrieved on March 29, 2014 from

[271]. http://www.google.co.uk/url?sa=t\&rct=j\&q=\&esrc=s\&frm=1\&source=web\&cd=2\&cad=rja\&uact=8\&ved=0CDUQFjAB\&url=http $\% 3 \mathrm{~A} \% 2 \mathrm{~F} \% 2 \mathrm{Fwww}$. londonstockexchange.com\%2Fstatistics $\% 2 \mathrm{Fnew}$-issues-further-issues $\% 2 \mathrm{Fnew}-$ issues.xls\&ei=FxI2U7ffKcWn0QXNuoDwAw\&usg=AFQjCNGiQglzzb-m1BI4rNwmvH7jJJN_pw\&bvm=bv.63808443,d.d2k

[272]. Lux, T., (2006). Herd behaviour, bubbles and crashes. The Economic journal, Vol. 105 No 431 (July),

[273]. P. 881-896. Retrieved on April 8, 2014 from http://www.msfinance.ethz.ch/pdfs/26.pdf

[274]. Macias, J.B., Massa, I. (2011). Finance-growth nexus: evidence from a top global reformer. Applied

[275]. Financial Economics, 2011, 21, 529-544. Retrieved on March 9, 2014 from http://web.a.ebscohost.com/ehost/pdfviewer/pdfviewer?vid=9\&sid=fa32ac6e-d16a-4170-b41a619bedba2c0e\%40sessionmgr4004\&hid=4101

[276]. Madon, S. (2000). The Internet and Socio-economic development: Exploring the interaction. London 


[277]. School of $\quad$ economics. $\quad$ Retrieved on $\quad$ March $\quad 31, \quad$ from
http://citeseerx.ist.psu.edu/viewdoc/download?doi=10.1.1.108.9673\&rep=rep1\&type=pdf

[279]. FROM INDIA. Economics, Management, and Financial Markets. Volume 8(2), 2013, pp. 110-127, ISSN 1842-3191. Retrieved on February $21, \quad 2014 \quad$ from $\quad$ http://web.a.ebscohost.com/ehost/resultsadvanced?sid=028f72f2-1f79-40e4-96cc6e71624a77f5\%40sessionmgr4002\&vid=2\&hid=4106\&bquery=financial+development\&bdata=JmRiPWJ0aCZ0eXB1PTEmc210ZT 1laG9zdC1saXZ1

[280]. Mahbub, U., H., Amartya, S. (1990). About Human Development. Retrieved on March 26, 2014 from

[281]. http://hdr.undp.org/en/humandev

[282]. Mansell, R., Steinmueller, W.E., Montalvo, U.W.D. (1999) LSE Research Online: May 2008.

[283]. Opportunities for knowledge-based development: capabilities, infrastructure, investment and policy. Science and public policy, 26 (2). pp. 91-100.DOI:10.3152/147154399781782572. Retrieved on March 31, 2014 from https://www.academia.edu/2996973/Opportunities_for_knowledge-

based_development_capabilities_infrastructure_investment_and_policy

[284]. Margues, L.M., Fuinhas, J.A., Marques, A.C. (2013). Does the stock market cause economic growth?

[285]. Portuguese evidence of economic regime change. Economic Modelling. May2013, Vol. 32, p316-324. 9p. retrieved on March 9, 2013 from http://web.a.ebscohost.com/ehost/search/advanced?sid=028f72f2-1f79-40e4-96cc$6 \mathrm{e} 71624 \mathrm{a} 77 \mathrm{f5} \% 40$ sessionmgr4002\&vid $=1 \&$ hid $=4106$

[286]. Maria-Lenuța, C., George, A.C., Alin, N.I. (2013). Theoretical aspects of financial liberalization

[287]. Process. Annals of the University of Oradea, Economic Science Series. Jul2013, Vol. 22 Issue 1, p867-875. 9p. Retrieved on April 22, 2014 from http://web.a.ebscohost.com/ehost/resultsadvanced?sid=4373bab0-52c8-4a21-9a27420245e6b67b\%40sessionmgr4001\&vid=2\&hid=4101\&bquery=Theoretical+aspect $\% 22$ of $\% 22+$ financial+liberalization + process \&bdata=JmRiPWJ0aCZ0eXB1PTEmc210ZT1laG9zdC1saXZ1

[288]. Marquis, C. Zhi, H. (2010). Acquisition as exaptation: The legacy of founding institutions in the US

[289]. Commercial banking industry. Academy of management journal. 2010. Vol.53. No 6. 1441-1473. Retrieved on March 15, 2014 fromhttp://web.b.ebscohost.com/ehost/pdfviewer/pdfviewer?vid=3\&sid=6b72932d-2307-4f5a-bea2568edc6ec4ce\%40sessionmgr198\&hid=117

[290]. Martin, H., Martin, N. (2009). PM draws the sword of morality, Return Northern Rock to mutual

[291]. Status, urges BSA. News I Lending Strategy I October 2009. Retrieved on April 19 , 2014 fromhttp://web.a.ebscohost.com/ehost/pdfviewer/pdfviewer?sid=4e845d68-4e2c-4ae8-946767c8e8e48056\%40sessionmgr4005\&vid=4\&hid=4101

[292]. Martinez, M. (2003). Business angels give funds, experience to emerging tech transfer companies:

[293]. New business model integrates many distributed companies within a region. Caribbean Business, Thursday April $10,2003$. Retrieved on April 10, 2014 from http://web.a.ebscohost.com/ehost/pdfviewer/pdfviewer?vid=9\&sid=fa32ac6e-d16a-4170-b41a619bedba2c0e\%40sessionmgr4004\&hid=4101

[294]. Mbutor, O.M., Uba, I.A. (2013).The impact of financial inclusion on monetary policy in Nigeria.

[295]. Research Department, Central Bank of Nigeria, Nigeria. Vol. 5(8), pp. 318-326, November, 2013. DOI: 10.5897/JEIF2013.0541. ISSN 2006-9812 (C2013 Academic Journals. Journal of economics and international finance. Retrieved on April 10, 2014 from http://www.academicjournals.org/article/article1383581296 Mbutor\%20and\%20Uba.pdf

[296]. McCall, M.W. (2004). Leadership development through experience. Doi:

[297]. 10.5465/AME.2004.14776183 ACAD MANAGE PERSPECT August 1, 2004 vol. 18 no. 3 127-130. Retrieved on April 11, 2014 from http://amp.aom.org/content/18/3/127.short

[298]. Mckinnon, R., Shaw, E., (1973) (Edited by Oosterbaan, M.S., Stveninck, T.R., Windt, N.V., 2000).

[299]. Determinants of Economic growth. Retrieved on March $18, \quad 2014 \quad$ from http://books.google.co.uk/books?id= tf LVVxgWkC\&pg=PA116\&lpg=PA116\&dq=ronald+mckinnon+1973+and+edward+shaw+1 973\&source=bl\&ots=dPk8W67xgU\&sig=AePtfvLiWFjrG3qKUyhTeUgu6Uw\&hl=en\&sa=X\&ei=GVgoU8ytNcX07AabvYDYAw \&ved=0CDMQ6AEwAQ\#v=onepage\&q=ronald\%20mckinnon\%201973\%20and\%20edward\%20shaw\%201973\&f=false

[300]. McMillan, D.G., Wohar, M.E. (2012). Output and stock prices: an examination of the relationship

[301]. over 200 years. Applied Financial Economics, 2012, 22, 1615-1629. Retrieved on April 15, 2014 from http://web.a.ebscohost.com/ehost/pdfviewer/pdfviewer?vid=14\&sid=e517e781-b16a-45f0-b6cd0a59d175cc02\%40sessionmgr4004\&hid=4101

[302]. Medland, D. (2014) Needed: More Corporate Whistle-Blowers And Their Stories -- All The Way To

[303]. Hollywood. Retrieved on April 19, 2014 from http://www.forbes.com/sites/dinamedland/2014/03/23/needed-more-corporatewhistleblowers-and-their-stories-all-the-way-to-hollywood/

[304]. Mintzberg, H., Ahlstrand, B., Lampel, J. (1998) Strategy Safari. A guided tour through the wilds of

[305]. strategic management P. 1-45. The Free Press, N.Y. ISBN 0-684-84743-4

[306]. Morales, M.F. (2003). Financial Intermediation in a Model of Growth Through Creative Destruction.

[307]. Retrieved on April 14, 2014 from http://pareto.uab.es/wp/2001/48701.pdf

[308]. Mougani, G., (2012). An Analysis of the Impact of Financial Integration on Economic Activity and

[309]. Macroeconomic Volatility in Africa within the Financial Globalization Context. Retrieved on March 7, 2014 from http://www.afdb.org/fileadmin/uploads/afdb/Documents/Publications/WPS\%20No\%20144\%20An\%20Analysis\%20of\%20the\%20I mpact $\% 20$ of $\% 20$ Financial $\% 20$ Integration $\% 20$ on $\% 20$ Economic $\% 20$ Activity $\% 20$ and $\% 20$ Macroeconomic $\% 20$ Volatility $\% 20$ in $\% 20$ Africa\%20\%20SS.pdf

[310]. NAICOM (2014) National Insurance Commission. Retrieved on April 19, 2014 from

[311]. http://naicom.gov.ng/

[312]. NCC (2014). Nigerian Communications commission (NCC) Monthly subscription data. Retrieved on
[313]. March 26, 2014 from http://www.ncc.gov.ng/index.php?option=com_content\&view=article\&id=125:art-statistics-subscriberdata\&catid=65:cat-web-statistics\&Itemid=73 and http://www.nationsencyclopedia.com/economies/Africa/Nigeria.htmld

[314]. NIPC (1995) (Nigerian Investment Promotion Commission). Legal and regulatory framework for

[315]. setting up business in Nigeria. Retrieved on April 8, 2014 from http://www.ngbaafrica.org/fileadmin/Downloads/DoingBusiness/NIPCRegulatoryFrameworkforSettingupBusinessinNigeria.pdf

[316]. Nsehe, M (2013). Africa's 50 Richest 2013: The Newcomers. Retrieved on April 11, 2014 from

[317]. http://www.forbes.com/sites/mfonobongnsehe/2013/11/13/africas-50-richest-2013-the-newcomers/

[318]. Nwadike, A. (2013). Discover Unexploited Revenues. Maximise Current Revenues. 
[319]. Manage Risks, Satisfy Customers. Nigerian Telecom sector: 10 Reasons Why Nigeria will give you best returns Telecom Advisory Services Limited. Retrieved on March 29, 2014 from http://www.enterprise-ireland.com/EI Corporate/en/ExportAssistance/International-Office-Network-Services-and-Contacts/Telecoms-and-ICT-Seminar-Telecoms-Advisory-ServicesNigeria.pdf

[320]. Nwogwugwu, I. (2014). The Naira is under attack. Back page This Day Newspaper, Monday 3 March,

[321]. 2014. Retrieved on April 6, 2014 from http://www.thisdaylive.com/articles/the-naira-is-under-attack-/172877/

[322]. Nzotta, S.M, Okereke, E.J. (2009). Financial Deepening and Economic Development of Nigeria: An

[323]. Empirical Investigation. African Journal of Accounting, Economics, Finance and Banking Research Vol. 5. No. 5. 2009. Retrieved on March 15, 2014 from http://globip.com/articles/african-vol5-article3.pdf

[324]. Odeniran, S.O, Udeaja, E.A. (2010). Financial Sector Development and Economic Growth: Empirical

[325]. Evidence from Nigeria. Central Bank of Nigeria Economic and Financial Review Volume 48/3 September 2010. Retrieved on March 14, 2014 from http://www.cenbank.org/Out/2012/publications/reports/rsd/efr2010/Economic\%20and\%20Financial\%20Review\%20Vol\%2048\%20No\%203,\%20September\%202010/Financial\%20Sector\%20D evelopment\%20and\%20Economic\%20Growth.pdf

[326]. O'Neill, I. (2008). Searching for Water and Minerals on Mars - Implications for Colonization. Retrieved on April 22, 2014 from http://www.universetoday.com/14037/searching-for-water-and-minerals-on-mars-implications-for-colonization/and http://www.universetoday.com/14037/searching-for-water-and-minerals-on-mars-implications-for-colonization/\#ixzz2ziDjduZc

[327]. O’Sullivan, A., Sheffrin, S. (2002) Economics: Principles in action. ISBN 13: 9780130630858

[328]. Osuji, C.C, Chigbu, E.E. (2012). An Evaluation of Financial Development and

[329]. Economic Growth of Nigeria: A Causality Test. Kuwait Chapter of Arabian Journal of Business and Management Review Vol. 1, No.10; June 2012. Retrieved on March 15, 2014 from http://www.arabianjbmr.com/pdfs/KD VOL 1 10/3.pdf

[330]. Oteh, A. (2014). Commodities Exchange Will Boost Agriculture Sector. Retrieved on April 14, 2014

[331]. from this day Newspaper. Monday, April, 14, 2014. From www.thisdaylive.com

[332]. Owusu, E.L., Odhiambo, N.M. (2012). The role of financial liberalization in Nigeria: A review of key

[333]. policy issues, economic management, and financial markets. Vol.7 (3), 2012. P89-107. ISSN 18842-3191. Retrieved on April 7 , 2014 from http://www.tandfonline.com/eprint/YetcdXvMfarNRZtm8Tjh/full\#.U0LftnRwbIU

[334]. Owusu, E.L., Odhiambo, N.M. (2012). The efficacy of financial liberalization in Ivory Coast.

[335]. Economics, Management, and Financial Markets. Volume 7(2), 2012, pp. 105-117, ISSN 1842-3191. Retrieved on April 12, 2014 from 619bedba2c0e\%40sessionmgr4004\&hid=4101

[336]. Pal, K. and Mithal, R. (2011).Impact of macroeconomic indicators on Indian capital markets. The

[337]. journal of risk finance. Vol. 12, No2, 2011. P. 84-97. Retrieved on March 8, 2014 from http://www.deepdyve.com/lp/emeraldpublishing/impact-of-macroeconomic-indicators-on-indian-capital-markets-Q3dPqX794g

[338]. Palley, T.I., (2008). The Relative Income Theory of Consumption: A Synthetic Keynes-Duesenberry-

[339]. Friedman Model> retrieved on April 3, http://scholarworks.umass.edu/cgi/viewcontent.cgi?article=1141\&context=peri_workingpapers

[340]. PENCOM (2009).The National Pension Commission (PENCOM).The pension reform act of 2004.

[341]. Retrieved on March 28, 2014 from http://www.pencom.gov.ng/index.php/component/content/article?id=154

[342]. Reuters. (2012)Nigeria's Lagos state issues \$507million bond at 14.5 percent, maturing in 2019.

[343]. Retrieved on March 26 from http://www.reuters.com/article/2012/11/23/nigeria-bond-lagos-idUSL5E8MN7DX20121123

[344]. Riley, G. (2012). What is Economic Development? Retrieved on March 26, 2014 from Development.

[345]. http://www.tutor2u.net/blog/index.php/economics/comments/unit-4-macro-what-is-economic

[346]. Ritter, J.R. (2013). Initial Public Offerings: Updated Statistics. Retrieved on March 29, 2014 from

[347]. http://bear.warrington.ufl.edu/ritter/IPOs2012Underpricing.pdf

[348]. Robbins, Lord (1968) the theory of economic development in the history of economic thought.

[349]. Retrieved on March 17, 204 from https://mises.org/books/economic_development_robbins.pdf

[350]. Roche, D. (2000). Cyber economy should fear only the Euro state. Euro money, 00142433, May2000,

[351]. Issue 373. Retrieved on March 7, 2014 from http://web.a.ebscohost.com/ehost/search/advanced? $\mathrm{sid}=028 \mathrm{f} 72 \mathrm{f} 2-1 \mathrm{f} 79-40 \mathrm{e} 4-96 \mathrm{cc}-$ 6e71624a77f5\%40sessionmgr4002\&vid=1\&hid $=4106$

[352]. Russell Investments (2014) Methodology matters. Retrieved on March 6, 2014 from

[353]. http://www.russellusindexes.com/pdfs/methodology-matters.pdf\&http://www.russellusindexes.com/russell-indexes.html

[354]. Safaricom (2014). M-PESA. Retrieved on March 26, 2014 from http://www.safaricom.co.ke/?id=257

[355]. Schumpeter, J.A. (1934). Theory of Economic growth. Retrieved on March 17, 2014 from

[356]. http://compaso.eu/wp-content/uploads/2013/01/Compaso2012-32-Croitoru.pdf

[357]. Schumpeter, J.A. (1939) BUSINESS CYCLES: A Theoretical, Historical and Statistical Analysis of the

[358]. Capitalist Process. Abridged, with an introduction by RendigsFels. Retrieved on March 21, 2014 from http://www.espiritodafenix.com/index arquivos/Arquivo/50 Schumpeter Ciclos de Negocios/schumpeter business cycles.pdf

[359]. SEC. (2010). Securities and Exchange Commission, Nigeria. Nigerian capital market Statistical bulletin

[360]. 2010. Retrieved on April 9, 2014 from http://www.sec.gov.ng/files/SEC\%20Nigeria\%20statitical\%20bulletin\%202010.pdf

[361]. Shane, S.A. (2009). FOOL's GOLD? The Truth behind Angel investing in America. Oxford University

[362]. Press. ISBN 978-0-19-533108-0

[363]. Shittu, A. I. (2012). Financial Intermediation and Economic Growth in Nigeria. British Journal of Arts

[364]. and Social Sciences. ISSN: 2046-9578, Vol.4 No.2 (2012) OBritish Journal Publishing, Inc. Retrieved on March 15, 2014 from http://www.bjournal.co.uk/paper/bjass 4 2/bjass 04 02 03.pdf

[365]. Siegel, D. (2013) The Future of Bank Product Strategies: How Creating a 360-degree View of the

[366]. Customer Leads to Better Growth. Retrieved on April 9, 2014 from https://www.perficient.com/Thought-Leadership/PerficientPerspectives/2013/Product-Strategy

[367]. Simon, H. (2012) Are Derivatives A Disaster Waiting To Happen? Retrieved on March 31, 2014 from

[368]. http://www.investopedia.com/tags/alternative investments/

[369]. Simon, J.L (1981). The Ultimate Resource by Julian Lincoln Simon published at Princeton

[370]. university press 1981 . Pg 360-390

[371]. Sims, E (2011). Graduate Macro Theory II: Notes on Investment. University of Notre Dame. Retrieved

[372]. on April 13, 2014 from http://www3.nd.edu/ esims1/investment notes.pdf

[373]. Singh, A. (2008). Stock markets in low and middle income countries. Centre for Business Research, 
[374]. University of Cambridge. Working Paper No. 377. CERF, Judge Business School, and Centre for Business Research, University of Cambridge. Retrieved on April 3, 2014 from http://ideas.repec.org/p/cbr/cbrwps/wp377.html

[375]. Sorkin, A.R. (2009). Too Big to Fail The Inside Story of How Wall Street and Washington Fought to

[376]. Save the Financial System---and Themselves. ISBN 9780670021253

[377]. Standard and Poor's (2012). S\&P U.S. Indices Methodology Retrieved on March 6t, 2014 from

[378]. http://www.standardandpoors.com/servlet/BlobServer?blobheadername3=MDTType\&blobcol=urldata\&blobtable $=$ MungoBlobs\&blobheadervalue $2=$ inline $\% 3 \mathrm{~B}+$ filename $\% 3$ Dmethodology-sp-usindices.pdf\&blobheadername $2=$ Content -

Disposition\&blobheadervalue $1=$ application $\% 2$ Fpdf\&blobkey=id\&blobheadername $1=$ contenttype \&blobwhere $=1244125623286 \&$ blobheadervalue $3=\mathrm{UTF}-8$

[379]. Stern, D.I (2004). The Rise and Fall of the Environmental Kuznets Curve World Development Vol. 32,

[380]. 8, pp. 1419-1439, 2004. Retrieved on April 8, 2014 from http://steadystate.org/wp-content/uploads/Stern_KuznetsCurve.pdf

[381]. Su, C.W., Chang, H.L., Pan, G. (2013). Tests for causality between insurance development and

[382]. economic growth using asymptotic and panel bootstrap distributions. Economic computation and economic cybernetics studies and research. 2013, Vol. 47 Issue 3, p111-131. 21p. reyrfieved on April 17, 2014 from http://web.a.ebscohost.com/ehost/detail?vid=5\&sid=606b8c70-8fdc-4fbc-93ed1a7601df41c3\%40sessionmgr4001\&hid=4107\&bdata=JnNpdGU9ZWhvc3QtbGl2ZQ\%3d\%3d\#db=bth\&AN=91026054

[383]. Sundaram, S., Willey, T. (2009). Derivatives by US banks: impact on risk and profitability. Retrieved

[384]. on April 18, 2014 from http://www.freepatentsonline.com/article/Indian-Journal-Economics-Business/214101898.html

[385]. Takamura, T. (2013). A General Equilibrium Model with Banks and Default on Loans. Canadian

[386]. Economic Analysis Department Bank of Canada Ottawa, Ontario, Canada K1A 0G9. Retrieved on April 9, 2014 from www.aeaweb.org/aea/2014conference/program/retrieve.php?pdfid=684

[387]. Taplin, R. (2013). Rio+20 - The Future We Want: Technology for sustainable development and green

[388]. economy leadership. International Journal of Technology Management \& Sustainable Development Volume 12 Number 3 @) 2013. Australian Centre for Sustainable Mining Practices, University of New South Wales. Retrieved on April 9, 2014 from http://web.b.ebscohost.com/ehost/pdfviewer/pdfviewer?vid=3\&sid=d35f635e-95bf-4485-a39928dbc8fdf568\%40sessionmgr113\&hid=117

[389]. The Economist (2013). Why does Kenya lead the world in mobile money? Retrieved on March 26,

[390]. 2014 from http://www.economist.com/blogs/economist-explains/2013/05/economist-explains-18

[391]. The Moscow Times (2014). S\&P Cuts Russia's Foreign Currency Ratings. Retrieved on April 29, 2014

[392]. from http://www.themoscowtimes.com/business/article/sp-cuts-russias-foreign-currency-ratings/498969.html

[393]. The Rational Walk (2010). Book Review: Lessons From Andrew Ross Sorkin’s “Too Big To Fail.

[394]. Retrieved on April 9, 2014 from http://www.rationalwalk.com/?p=4046

[395]. THISDAY Newspaper (2014). Nigeria now 26th largest economy in the world, GDP hits \$510billion.

[396]. Beyond the rebasing, a lot to be done. Monday 7 April, 2014. Vol. 19. No 6922. Can be retrieved from www.thisdaylive.com

[397]. Thumrongvit, P., Kim, Y., Pyun, C. (2013). Linking the missing market: The effect of bond markets on

[398]. economic growth. International Review of Economics \& Finance. Jun2013, Vol. 27, p529-541. 13p. retrieved on March 7, 2014 from 6e71624a77f5\%40sessionmgr4002\&vid $=1 \&$ hid $=4106$

[399]. Toivanen, O. (2009) Entrepreneurship, Innovation and Development: Lessons from Finland. United

[400]. Nations University: World institute for development Economic Research. Retrieved on April 11, 2014 from http://www.wider.unu.edu/publications/newsletter/articles/en GB/Toivonen-article-Oct-09/

[401]. Torrisi, G. (2009). Public infrastructure: definition, classification and measurement issues. Retrieved

[402]. on March, 2014 from http://ideas.repec.org/p/pra/mprapa/12990.html

[403]. Tower Watson (2013). Global pension asset study 2013. Retrieved on March 28, 2014 from

[404]. http://www.google.co.uk/url?sa=t\&rct=j\&q=\&esrc=s\&frm=1\&source=web\&cd=1\&ved=0CC4QFjAA\&url=http $\% 3 \mathrm{~A} \% 2 \mathrm{~F} \% 2 \mathrm{Fww}$ w.towerswatson.com\%2FDownloadMedia.aspx\%3Fmedia\%3D\%257B5AC4BED2-A4F9-4C9E-AB9D5087579BF96D\%257D\&ei=dPg1U8uKF8Px0gXVi4Ao\&usg=AFQjCNEMRZiMCt5f62IyqX_bm8GkCz27g\&bvm=bv.63808443,d.d2k

[405]. Trondsen, E (2012). Finnish Entrepreneurship, Seed Funding and Support. Retrieved on April 11,

[406]. 2014 from http://siliconvikings.com/news/-finnish-entrepreneurship-seed-funding-and-support/

[407]. Uddin, G.S., Shahbaz, M., Arouri, M., Teulon, F. (2014). Financial development and poverty reduction

[408]. nexus: A cointegration and causality analysis in Bangladesh. Economic Modelling. Jan2014, Vol. 36, p405-412. 8p. Retrieved on April 7, 2014 from http://web.a.ebscohost.com/ehost/resultsadvanced?sid=028f72f2-1f79-40e4-96cc6e71624a77f5\% 40sessionmgr4002 \&vid=2\&hid=4106\&bquery=financial + development $\& b d a t a=J m R i P W J 0 a C Z 0$ eXBIPTEmc210ZT $11 \mathrm{aG} 9 \mathrm{zdC} 1 \mathrm{saXZ1}$

[409]. Uko, N.A. (2013). Nigeria: Contributory Pension Assets Hit N3.72 Trillion. All Africa. Retrieved on

[410]. March 28, 2014 from http://allafrica.com/stories/201311050203.html

[411]. UN (2013). Human Asset index: Development Policy and Analysis Division, Department of economic

[412]. and social affairs (DESA), United Nations. Retrieved on April 1, 2014 from http://www.un.org/en/development/desa/policy/cdp/ldc/ldc criteria.shtml/thai

[413]. UNCTAD (2012).Foreign direct investment to Africa increases, defying global trend for 2012: United

[414]. Nations Conference on Trade and Development 2012. Retrieved on March 26, 2014 from http://unctad.org/en/pages/PressRelease.aspx? OriginalVersionID=136

[415]. UNCTAD (2013). World Investment Report 2013: Annex Tables. RETRIEVED ON March 30, 2014 from

[416]. http://unctad.org/en/pages/DIAE/World\%20Investment\%20Report/Annex-Tables.aspx

[417]. UNDP (2013) Human Development Report 2013. The Rise of the South: Human Progress in a Diverse

[418]. World. Published by the United Nations development Program (UNDP). Retrieved on March 26, 2014 from http://hdr.undp.org/sites/default/files/reports/14/hdr2013 en complete.pdf

[419]. University of Texas at Dallas (2014). Online lecture: Chapter 11. The nature of financial

[420]. intermediation. Retrieved on March 18, 2014 from http://www.utdallas.edu/ chaf/ba4345/trans/ch11.ppt @ http://www.google.co.uk/url?sa=t\&rct=j\&q=\&esrc=s\&frm=1\&source=web\&cd=2\&ved=0CDsQFjAB\&url=http\%3A\%2F\%2Fww w.utdallas.edu $\% 2 \mathrm{~F} \sim$ chaf $\% 2 \mathrm{Fba} 4345 \% 2 \mathrm{Ftran} \% 2 \mathrm{Fch} 11$.ppt\&ei=tHYnU-

GKFoWw7Aa3yoCwCw\&usg=AFQjCNGYxaGR1y1yrt2Rk-ghhVBbLc3sbA\&bvm=bv. 62922401,d.ZGU

[421]. UNRISD (2012) United Nations research Institute for Social Development: Social Dimensions of 
[422]. Green Economy and Sustainable Development http://www.unrisd.org/greeneconomy

[423]. USGS (2014). The water in you: what does water do for you? The USGS water science school.

[424]. Retrieved on April 24, 2014 from http://water.usgs.gov/edu/propertyyou.html

[425]. Vaghely, I.P. Julien, P. (2008). Are opportunities recognised or constructed: An information

[426]. perspective on entrepreneurial opportunity

e807a6195b0f\%40sessionmgr112\&hid=128\&bdata=JnNpdGU9ZWhvc3QtbGl2ZQ\%3d\%3d\#db=bth\&AN=45416530

[427]. Van den Berg, H. (2012). Economic growth and development (Second Edition) ISBN 13 978-981-

[428]. 4374-64-4

[429]. Vector Grader. (2014) Market cap to GDP Ratio. Retrieved on March 20, 2014 from

[430]. http://www.vectorgrader.com/indicators/japan-market-cap-gdp

[431]. Washington Blog (2012). FINANCIAL IMPLOSION: Global Derivatives Market at \$1,200 Trillion Dollars

[432]. ... 20 Times the World Economy. Retrieved on M arch 31, 2014 from http://www.globalresearch.ca/financial-implosion-globalderivatives-market-at-1-200-trillion-dollars-20-times-the-world-economy/30944

[433]. Weafer, C. (2014) Crimean Crisis Will Exacerbate Capital Flight. The Moscow Times.

[434]. http://www.themoscowtimes.com/opinion/article/crimean-crisis-will-exacerbate-capital-flight/495611.html

[435]. WEF (2011). World Economic forum: Financial Development Report 2009-2012. Retrieved on March

[436]. 14, 2014 from http://www.weforum.org/issues/financial-development

[437]. White, B (2011) Do Angel Investors exist in Africa. Retrieved on March 30, 2014 from

[438]. http://vc4africa.biz/blog/2011/04/06/do-angel-investors-exist-in-africa/

[439]. Whittington, M. (2012). Water on Mars May Not Mean Life, but May Mean Trouble. Retrieved on

[440]. April 22, 2014 from http://news.yahoo.com/water-mars-may-not-mean-life-may-mean-184000993.html

[441]. Wilshire Index (2014) retrieved on March 6, 2014 from http://www.wilshire.com/indexes/\&

[442]. http://www.wilshire.com/Indexes/calculator/\&http://web.wilshire.com/Indexes/Broad/

[443]. Winton, A. Gorton, G. (2002)). Reasons for financial intermediation. Wharton School. Retrieved on

[444]. March 18, 2014 from http://fic.wharton.upenn.edu/fic/papers/02/0228.pdf

[445]. Wong, A. (2010). Angel finance: the other Venture Capital. Douglas Cummings (editor) Venture

[446]. capital: investment strategies, structures, and policies. KOLB series in Finance. John Wiley. ISBN 978-0-470-49914-6

[447]. World Bank (2012) market cap to GDP Ratio. Retrieved on March 20, 2014 from

[448]. http://data.worldbank.org/indicator/CM.MKT.LCAP.GD.ZS

[449]. World Bank (2013). Automated teller machines (ATMs) (per 100,000 adults) Automated teller

[450]. machines are computerized telecommunications devices that provide clients of a financial institution with access to financial transactions in a public place. International Monetary Fund, Financial Access Survey. Retrieved on March 30,2014 from http://data.worldbank.org/indicator/FB.ATM.TOTL.P5

[451]. World Bank (GFDR, 2014) Global financial development report: financial inclusion (2014) Retrieved

[452]. on March 19, 2014 from https://openknowledge.worldbank.org/bitstream/handle/10986/16238/9780821399859.pdf?sequence=4

[453]. World Population Review (2014).Nigerian population 2014 (173,611,131). Retrieved on April 9, 2014

[454]. from http://worldpopulationreview.com/countries/nigeria-population/

[455]. Yudhoyono, S.B., Sirleaf, E.J., Cameron, D. (2013). A new global partnership: Eradicate poverty and

[456]. transform economies through sustainable development. The Report of the High-Level Panel of Eminent Persons on the Post-2015 Development Agenda. Retrieved on April 1, 2014 from http://www.un.org/sg/management/pdf/HLP_P2015_Report.pdf

[457]. Yunus, M. (2013). Micro credit. Grameen Bank: Bank for the poor. Retrieved on March 28, 2014 from

[458]. http://www.grameen-info.org/index.php?option=com content\&task=view\&id=23\&Itemid=126

[459]. Yurcan, B. (2013). The future of multi-channel banking. Retrieved on March 27, 2014 from

[460]. http://www.banktech.com/channels/the-future-of-multichannel-banking/240149919

[461]. Zoltan, J., Audretsch, D.B., Lehmann, E.E (2013). The knowledge spill over theory of

[462]. entrepreneurship. Small Business $\quad$ Economics. Dec2013, Vol. $41 \quad$ Issue 4 , p757-774. 18p.http://web.b.ebscohost.com/ehost/detail?vid=5\&sid=2bd4e11b-2267-4a11-918ae807a6195b0f\%40sessionmgr112\&hid=128\&bdata=JnNpdGU9ZWhvc3QtbGl2ZQ\%3d\%3d\#db=bth\&AN=91993239 